\title{
What Are the Headwaters of Formal Savings? Experimental Evidence from Sri Lanka Faculty Research Working Paper Series
}

\section{Michael Callen}

Harvard Kennedy School

\section{Suresh De Mel}

University of Peradeniya

\section{Craig McIntosh}

University of California, San Diego

\section{Christopher Woodruff}

University of Warwick

\section{March 2015 RWP15-011}

Visit the HKS Faculty Research Working Paper Series at:

https://research.hks. harvard.edu/publications/workingpapers/Index.aspx

The views expressed in the HKS Faculty Research Working Paper Series are those of the author(s) and do not necessarily reflect those of the John F. Kennedy School of Government or of Harvard University. Faculty Research Working Papers have not undergone formal review and approval. Such papers are included in this series to elicit feedback and to encourage debate on important public policy challenges. Copyright belongs to the author(s). Papers may be downloaded for personal use only. 


\title{
Acknowledgements
}

We thank the Consortium on Financial Systems and Poverty at the University of Chicago and the International Growth Centre for financial support for the project. Kandy Consulting Group provided excellent service in carrying out the baseline and follow-up surveys and assisting in carry out the interventions on which the project is based.

(C) 2014 by Michael Callen, Suresh De Mel, Craig McIntosh, and Christopher Woodruff. All rights reserved. Short sections of text, not to exceed two paragraphs, may be quoted without explicit permission provided that full credit, including (C) notice, is given to the source.

\begin{abstract}
When households increase their deposits in formal bank savings accounts, what is the source of the money? We combine high-frequency surveys with an experiment in which a Sri Lankan bank used mobile Point-of-Service (POS) terminals to collect deposits directly from households each week. In this context, the headwaters of formal savings are to be found in sacrificed leisure time: households work more, and work more on the wage market when savings options improve. These results suggest that the labor allocation channel is an important mechanism linking savings opportunities to income.
\end{abstract}




\section{INTRODUCTION.}

In recent years, there has been a strong push - in developed and developing countries alike to provide financial services that bring the savings of the unbanked into formal institutions. The surge in interest in formal savings stems from a recognition of its potential to improve the efficiency of the overall economy by increasing the depth of financial markets, and from increased understanding of its potential to improve the lives of people, most of them poor, who do not use banks. The effect of formal savings on the poor is the subject of a great deal of recent theoretical and empirical work. Neo-classical models suggest that formal savings can improve welfare by raising effective interest rates and encouraging the formation of savings stocks that can be used both for buffering and for future investment (Deaton 1991). More recently, the literature has pointed to issues of self-control (Laibson 1997) and other-control (Anderson and Baland 2002) as impediments to savings. Commitment products (Benartzi and Thaler, 2003; Ashraf, Karlan, and Yin, 2005) and savings accounts that provide individuals within the household greater autonomy over savings (Ashraf, 2009) may overcome these obstacles. Finally, a literature in development suggests that in the presence of non-convexities in the production function, tools that help entrepreneurs accumulate savings can have transformative effects, allowing them to achieve higher steady-state returns and potentially to escape low-investment poverty traps (Banerjee and Newman 1993).

Half of adults worldwide remain unbanked, but 35 percent of the unbanked report obstacles to saving that can be overcome by improvements to products and regulation (Demirguc-Kunt and Klapper, 2012). The empirical evidence is striking: several recent studies show remarkably large positive effects on household expenditures resulting from increased access to standard savings accounts (Dupas and Robinson 2012, Brune et al 2013, Prina 2013, Schaner 2013). These findings raise two important questions: What is the source of the savings that are accumulated, and what is the channel through which the effects are realized? On the first, the existing studies have little to say, largely because they are typically based on data from a baseline survey and a single follow-up survey. ${ }^{1}$ On the second, the literature has focused on examining two channels for these effects. First, savings may allow households to save to make indivisible investments. Second, savings accounts may help individuals protect cash from either their own time-inconsistent selves or from requests made by family or social networks. The reduction in transfers frees funds for direct expenditures or for investments that generate increases in income. While follow-up surveys often show dramatic effects

\footnotetext{
${ }^{1}$ An exception is Dupas and Robinson (2012) which use data from log books with daily entries for a period of three months following treatment. However, compliance with completing the logbooks was an issue.
} 
on household expenditures - a 'magic income effect' - the source of the savings and the specific channel are often difficult to pin down because of the length of time between treatment and followup.

We present the results from a similar experiment, but one that brings much more data to the analysis. We offered weekly, door-to-door savings deposit collection services to a randomly selected subset of a sample of individuals in rural Sri Lanka. Savings were collected by an agent of a large national savings bank in Sri Lanka. Using a wireless point of service (POS) terminal, agents provided a receipt for the deposit, showing the new account balance, on the spot. Starting five months before the collections began and continuing 13 months afterward, we collected detailed monthly survey data, including income, expenditure and labor market activity data. The weekly POS deposit collection service leads to large increases in savings. The number of transactions with formal financial institutions per month quadruples as a result of the treatment, the flow of savings into bank accounts almost doubles, and overall savings increase by more than 15 percent per month, or about US\$7, according to our findings.

This high-frequency, high-quality data collection was designed to allow us to say something about the source of the savings, but the data also allow us to examine in much more detail than available in previous studies the specific channel through which the savings accounts impact households. Given that enterprise investment is the most obvious channel through which savings could generate large changes in income, our results appear to present a puzzle. We find large increases in income alongside significant dis-investment in microenterprises, both induced by a relatively small push to save. Furthermore, the increase in income occurs immediately after the savings accounts are offered (it is clearly visible in the first month of post-treatment savings behavior). Thus, though the investment channel may be important in the longer term, it is a poor candidate for explaining the link between savings and income or expenditures in our study.

This finding leads us instead to focus attention on how the change in financial services affects an individual's optimal allocation of time between leisure and labor, and then between wage work and self-employment. We resolve the puzzle of our results by adapting to the setting a very standard neo-classical model from the macro literature, owing to Blanchard and Fischer (1989). In this framework, the treatment has an immediate effect on income and savings because an increase in the interest rate realized on savings leads households to choose to work more. In the context of constant marginal returns to labor effort in wage work and decreasing marginal returns to labor 
effort in self-employment, we show that the model also implies shifts from self-employment to wage work. ${ }^{2}$

The data match the predictions of the simple neo-classical framework remarkably well. We view this as very strong evidence that the labor / leisure channel is an important piece of the answer to both the question of the headwaters of savings and the question of the channel through which savings affects expenditures. We then use our detailed survey data to explore the channels that have received most of the attention in the previous literature. We find little support for any effect operating through capital investments, but uncover more mixed evidence on the "protection from self" and "protection from others" channels. The account for which deposits were collected is a standard savings account with no restrictions on withdrawals. However, the agents making collections cannot process withdrawals, and so obtaining the money deposited requires a trip to the bank branch, five to 10 kilometers from the area where collections were taken. Because this is costly, our savings product does include a commitment savings dimension. With regard to protection from self, we have fairly standard measures of individual time inconsistency. These suggest that the effect of treatment on savings balances is somewhat larger for individuals who are more time inconsistent.

The account may also allow individuals to avoid making transfers requested by family members or social networks. Note that the idea that formal savings would find their headwaters in money otherwise used for savings through social networks presents a real problem for welfare analysis in RCTs of formal savings products. This pattern could indicate that the private benefit of individuals in the treatment generates a negative spillover to others within savings networks, and hence experiments could lead to biased policy conclusions. To tackle this issue empirically, we focused on the interplay between our treatment and the rotating savings and credit associations (ROSCAs, Gugerty 2005) which are called seetus in Sri Lanka. We implemented a "randomized saturation" experiment (Crépon et al. 2013, Baird et al. 2014) whereby we drew in a sample of informal savings networks and directly randomized the fraction of each network offered the individual home POS deposit collection service. The strong tradition of seetus in Sri Lanka provides a well-defined form of financial network within which to examine this question. By tracking how the financial fortunes of those in these informal savings networks respond to the intensity of

\footnotetext{
${ }^{2}$ Banerjee et al (2013) develop a model to structure an analysis of the effects of an expansion of a micro credit program in India. They also show that the increase in credit can lead to an increase in labor. Intuitively, their effect comes from the fact that credit makes the purchase of durable goods possible, and hence raises the marginal benefit of consumption. In our framework, savings accounts increase the labor effort immediately because the higher interest rate increases the benefit of future consumption.
} 
treatment around them, we gain a very clear lens on the interaction between formal and informal financial services. We find that participation in rotating savings and credit associations actually increases as the fraction of the seetus' members provided the formal alternative goes up, suggesting that formal savings may complement participation in seetus. These results are consistent with the idea that households avoid using financial services that require disciplined payment schedules for fear of being unable to make the regular contributions required. Therefore the buildup of liquid bank balances engendered by the weekly home POS visits permits them to expand their use of credit and of informal savings vehicles. The results are not consistent with the savings accounts being used to protect savings from others, since the accounts are substitutes for seetus in this respect.

While our results match the labor / leisure framework quite well, they run counter to the current literature in a couple of important ways. Against the backdrop of a literature suggesting that use of formal financial institutions should complement entrepreneurial investment (Banerjee and Newman 1993) and substitute for informal savings mechanisms (Attanasio and Rios-Rull 2000), we find the reverse, at least over the first 24 months of the program. Like other recent studies of changes in access to savings accounts, we find a large "magical" income effect. But our data allow us to trace this to adjustments in labor hours, and in our case this occurs in the presence of a decrease rather than an increase in business scale. However, the reduction in inventories is again consistent with the neoclassical model: if enterprise owners equate the marginal return on inventory investments to the rate they would earn on savings, then an increase in the savings interest rate will induce them to reduce inventory investments. Self-employment rates decrease and wage income increases after households gain access to the savings treatment (although it is of course possible that savings will be re-invested in business over the longer run). What is surprising about our results is that we reject the non-convex model and yet still find savings to have a transformative effect on income. This ability to substitute into wage labor is at least partly a function of the very active day labor markets in our sample area. While this may not be representative of all areas in developing countries, there are likely to be numerous unbanked individuals on this margin in many contexts.

The remainder of the paper is structured as follows: Section 2 presents the background and design of the experiment, and Section 3 develops a simple framework to organize the analysis. Section 4 presents the impact of the program on savings, the "headwaters" of personal liquidity, and on entrepreneurial activity. Section 5 considers alternative explanations, discussing capital investments, heterogeneity with respect to individual time inconsistency, and the results on the randomized saturation experiment within the seetus, and Section 6 concludes. 


\section{SURVEY AND EXPERIMENTAL DESIGN.}

\subsection{Sampling and Treatment.}

In 2008, Sri Lanka's National Savings Bank (NSB) began a program of remote deposit collection targeted at business owners within one kilometer of NSB branches. The collections are made using a wireless Point of Service (POS) terminal carried by a bank agent traveling by motorcycle. The POS terminal allows deposits to be recorded in the bank's accounts immediately; the depositor receives a deposit confirmation showing the new account balance. Agents typically visit a given merchant once per week.

For this project, NSB agreed to provide branches in the towns of Bandarawela and Mahiyangana with an additional POS terminal and agent to make collections from more remotely located rural areas. While NSB's goal for the initial POS program was to reach highly liquid merchants, the goal of this project was reaching lower-income, under-banked households in more remote locations. We agreed on selecting areas by first going 5 to 10 kilometers from the branch along the main roads leading away from the two towns, and then taking households within one kilometer of the main road. Selected households in these areas were to be offered weekly door-todoor deposit collection services. We began by conducting a screening survey in these areas, listing all economically active adults in the households. The screening survey collected information on the frequency of pay from employment, whether or not the individual had a bank account, and if so whether they had made any banking transaction within the past month, and whether the individual participated in one or more seetus. We also noted whether the household was accessible by motorcycle, since that was a requirement for the collection service. A total of 5,081 individuals in 3,657 households were listed.

Before drawing the sample, we eliminated individuals whose profile made the weekly POS collection either infeasible or inappropriate. The first group included those living in houses that were not reachable by motorcycle. By this criterion, the house had to be within 500 feet of a point accessible to the agent via motorcycle. We also eliminated those who received income payments less frequently than once per week. The weekly collection is of most value where income streams are either daily or weekly. In practice, this means the sample is largely made up of individuals who are either self-employed or daily wage workers. This is important to keep in mind, because the daily paid workers may have more ability to change hours worked than, for example, monthly salary workers. Finally, we eliminated those who had made a deposit in a bank account within the past month, since 
we expected the behavior of those using the bank regularly would not be affected as much by the deposit collection services. Note that the last two criteria were applied at the individual level, so that if any listed member of the household received income payments at least weekly and had not used a bank account in the previous month, that individual remained eligible even if the criteria eliminated other household members.

NSB quite reasonably felt that their agents could not refuse a deposit from anyone approaching them while making their rounds. Therefore, we knew we would need to conduct the randomization at the level of clusters of houses. Agriculture is the primary activity in the sampled areas around both towns. The main crops are tea and vegetables around Bandarawela and rice and vegetables around Mahiyangana. The households are scattered into small clusters rather than distinct villages. We identified 156 distinct clusters of households (hereafter referred to as 'zones'), separated by at least a stretch of road long enough to make spillovers between treatment and control zones unlikely.

With these clusters in mind, we selected the project sample in several stages. Because we are particularly interested in the interaction between formal and informal savings, we began by selecting a sample of individuals who participate in a seetu in which all of the members reside within one kilometer of the individual. We refer to these as "close seetus." The first step was to select an individual in each cluster who is a member of a close seetu. There were 93 zones with at least one member of a close seetu. We re-surveyed these 93 individuals to collect the list of names of other participants in their seetu.

The second step of the sampling was aimed at achieving gender balance. The listing yielded a much smaller number of women than men meeting the employment / earnings frequency criteria. We therefore next selected up to five women in each of the zones. There were more than five women in only two of the 156 zones, implying that we selected essentially all of the women in the listing who qualified by the earning frequency and bank transaction criteria. We then extended the sample by selecting one male randomly from each zone. ${ }^{3}$ Finally, for each close seetu we then randomly selected 20 percent of its membership to participate in the survey. The resulting intake sample of 829 has 432 women and 397 men. Between August 2010, when the baseline was conducted, and November 2010, when the randomization was carried out, 34 respondents attrited from the survey, leading to an experimental sample of 795 who were included in the randomization.

\footnotetext{
${ }^{3}$ Because some zones have no males, we select up to two additional males per zone and use those to fill the remaining sample.
} 
Around 45 percent of the sample (360) are members of close seetus, with the remainder (435) coming from the broader random selection.

The randomization of collection services was carried out at the zone level, stratifying and balancing on data from the baseline survey. We stratified on quartiles of total savings balances, above/below median of household expenditures and whether the zone included a close seetu or not. We then re-randomized to achieve balance on a set of variables related to savings behavior and income generation. ${ }^{4}$ The study sample thus consists of 78 zones with 389 individuals for treatment and 78 zones with 406 individuals for control. ${ }^{5}$

Finally, we exploited the additional listing of seetu members to introduce a randomized saturation experiment in order to investigate the relationship between formal and informal savings instruments. We began from the group of 39 close seetus that had been selected into the treatment, each of which had $20 \%$ of its membership in the household survey. We then took one third of these groups and selected an additional $20 \%$ of their members, and another third to an additional $40 \%$ of their members, to be offered the treatment (but not to participate in the survey). Therefore, we survey $20 \%$ of their members of all of the close seetus in the study. With respect to treatment, 45 of the close seetus are untreated, 13 are treated at 20\%, 13 are treated at 40\%, and 13 at 60\% saturation. The comparison of the fortunes of the constant $20 \%$ of members studied across the randomized variation in the treatment saturation allows us to isolate externality effects of formal financial services on the welfare of the membership of informal savings networks.

In December 2010 we offered to open accounts at the local NSB branch for those selected into treatment. The account opening required that the individual come to the bank branch. During the first two weeks of the month, project research assistants were at the bank branches to help participants with the required paperwork. The minimum balance required to open an account is 500 LKR ( \$4.50); we paid this for all of the treated individuals who opened an account. ${ }^{6}$ Of the 389 individuals selected for treatment, 347 (89 percent) opened an account. POS collection services began 13 December in both branches. One main road from town was serviced each day of the week.

\footnotetext{
4 The variables on which we balanced were agricultural employment, education, gender, present bias, monthly income, whether the individual had a formal bank account, balances of formal and informal savings, total and informal monthly savings amounts, and whether anyone in the household was either a grantor or recipient of an outstanding informal loan.

${ }^{5}$ Seetu members who were brought into the study through the listing of all seetu members received treatment based on their zone of residence, not on the status of their respective seetu seed.

${ }^{6}$ The opening deposit is trivial relative to median income of the participants $(22,000 \mathrm{LKR})$. The exchange rate during the course of the study was approximately 111 LKR per US dollar.
} 


\subsection{Surveys and administrative data}

We conducted a baseline and three additional pre-treatment surveys for the full sample at monthly frequency between August and November 2010. We randomly allocated 498 households to a sample in which we continued to conduct monthly surveys and 297 households to a sample in which we conducted quarterly surveys. This both reduced survey costs and allows us at least a partial test of whether survey frequency affects deposit or aggregate savings behavior. For both monthly and quarterly survey groups, we conducted surveys at the defined frequencies through Nov 2011 (not Jan 2012). We then conducted monthly surveys in Dec 2011 and Jan 2012 and longer term follow-up surveys in July 2012 and Jan 2013. Thus, for the monthly survey sample, we have five pre-treatment, 15 post-treatment surveys - 13 monthly plus the two semi-annual surveys; for the quarterly survey sample have four pre-treatment and eight post-treatment surveys - four at quarterly intervals plus two monthly surveys and the two semi-annual surveys. Six months into the main experiment, we began a series of unbundling experiments whose impact is described in de Mel et al. (2013). The unbundling experiment was conducted in a randomly selected and well-balanced subset of the control and weekly home visit treatment arms. To avoid confounding the primary results, we drop the 192 treatment and 150 control individuals involved in the unbundling exercise as soon as that experiment began. Appendix Table 1 details the timing of the surveys, and shows which surveys are included in the sample we use here. The result is a full 30 months of data for the core sample (92 zones; 18 months at high frequency) and the 12 months prior to the beginning of the unbundling experiment for a subsample of 64 zones. Results are very similar if we use only the sample of 92 zones, but the precision of the short-term estimates is improved by the inclusion of the additional group that receives the core treatment for six months. Our analyses uses individual-level fixed effects and we cluster standard errors at the individual level as a straightforward way of accounting for the substantial autocorrelation present in high-frequency household data.

We undertook this project with the aim of answering the simple but vexing question: what is the root source of money that is newly brought into the formal financial sector? When people begin to use formal savings, what other behaviors in the household change to allow this liquidity to be deposited in a bank? Candidate explanations are that saved capital is substituted from cash in the mattress, that greater discipline from formal savings causes expenditures to decrease, that formal savings come at the cost of informal mutual insurance networks, or that some new source of income is engendered by the savings. The survey was designed with these sources in mind. The heart of the 
survey instrument is a cash flow analysis for the individual being sampled; the selected individual was always the respondent. In order to unpack the headwaters of formal finance, we need to be able to construct balances of financial flows at both the individual and the household level. Thus, our survey was designed to capture monthly liquidity flows in and out of both the respondent's personal finances as well as the overall household. Individual members of a household may not know how other members of the household spend money, or even how much income other members receive. We focus on the expenditures and transfers - both within and outside the household - which the individual participant made during the previous calendar month. The enumerators were trained to check that the sources of cash matched the uses of cash for the individual. Where the initial responses yielded differences, the enumerators pointed out the inconsistency and re-asked the income and expenditure questions. ${ }^{7}$

Individuals were first asked how much cash they received from earnings or withdrawals from formal or informal savings, from transfers from other members of the household, and from transfers or loans from outside the household. These amounts were summed and the respondent was asked whether the sum matched the total cash received during the month. They were then asked how much money they transferred to their spouse, their children, other household members and to anyone outside the household. Next, respondents were asked whether they had deposited any funds in a bank, increased the amount of cash they held, or saved the money informally through seetus or other means. The total cash received less transfers and changes in savings should represent the expenditures by the individual during the month. We asked for amounts spent by the individual in 33 expenditure categories. Enumerators then checked the sum of expenditures against the implied sum of expenditures and rectified any differences.

There is a tradeoff in this method of eliciting cash flow. On the one hand, we focus on data the participant certainly knows best. On the other hand, we would be limited in answering the "headwaters" question if the changes in income, expenditure, or savings come from changes in the behavior of other members of the household. That is, if we identify that increases in savings in banks are associated with increases in transfers from the spouse, we do not know whether the spouse decreased his expenditures, increased his income, or decreased his formal or informal

\footnotetext{
7 Samphantharak and Townsend (2009) assign mismatches in monthly income and expenditure to changes in cash holding. We measure cash holdings along with other financial assets. To the extent that individuals do not want to report increases in cash holdings, they might be tempted to increase reported expenditures instead. However, over years of conducting surveys in Sri Lanka, we have found respondents to be generally very willing to discuss financial matters openly, and we do not detect any patterns in the data which suggest significantly mis-reported cash balances.
} 
savings. We therefore also ask the respondent about aggregate household income and expenditures. Though we expect these data to be somewhat noisier, because the respondent may not be fully informed about the behavior of other household members, the data allow us to identify the sources of changes in savings arising from income and expenditure patterns of other household members.

In addition to the detailed survey data, we have administrative data from NSB for the accounts directly linked to the project. These detail each deposit and withdrawal, as well as other transactions (e.g., interest payments). We use the institutional data in this paper to study the determinants of uptake and account usage (Table 1) and institutional balances (Table 2); all of the remaining impact tables rely exclusively on information from the household surveys. ${ }^{8}$

\subsection{Balance and attrition}

Appendix Table 2 examines correlates of survey attrition. Overall, the resurvey rates were high. Ignoring attrition from the sample that occurred prior to the assignment of treatment, only 13 out of 795 individuals were not surveyed at least twice pre-treatment and twice post-treatment (our criterion for inclusion in the panel sample). We also examine the 20 individuals who did not complete the last high-frequency survey (wave 18 in January of 2012). More importantly, attrition does not differ in the treatment and control groups whether we examine simple differences between the two groups or we control for other covariates.

Appendix Table 3 examines the balance of the experiment. Treatment was assigned at the zone level, and the randomization was stratified on whether a zone contained a 'close' seetu (meaning that all the members of the seetu were resident in that zone), as well as on average household expenditures and baseline average savings in each zone. Stratification was done using baseline (round 1) data, and we test for balance using the remaining pre-treatment waves (rounds 25). Appendix Table 3 shows balance on a range of variables measuring savings, income and expenditure. Only one of the 35 variables tested shows any difference, and then only at the 10 percent level.

Despite the excellent overall balance of the experiment, the number of units to which treatment was assigned was relatively small (156), and due to sampling rules intended to locate as many self-employed females as possible, there is substantial cross-zone variation within the sample in variables such as gender and seetu participation. For example, 28 zones contain all male and 10

\footnotetext{
${ }^{8}$ Our analysis of a subsequent unbundling experiment takes place within the treatment group and hence makes extensive
} use of the institutional data; see de Mel et al. (2013). 
zones all female core respondents. Potentially due to this clustering of gender by zone, the experiment is imbalanced when we look among men only or among women only. ${ }^{9}$ Figure 1 shows the densities of one of the most severely imbalanced variables, the log of personal income. While the imbalances are not visually severe, the figure illustrates how the problems within men and within women counteract each other to lead to a full treatment/control comparison that is well balanced. ${ }^{10}$ The three other subgroups used later in the analysis (the self-employed, those with bank loans, and seetu members) are all well-balanced within subgroup. Given this issue, we focus the analysis on whole-sample comparisons and discuss imbalance issues carefully when we move to the analysis of the seetu experiment in Section 5.

\section{THEORETICAL FRAMEWORK}

Given the distance to the bank branches, regular use of a bank savings account may have been impractical for project participants. Providing weekly savings collection makes a new, reliable, form of savings available. For a number of reasons, the NSB account could represent an increase in the interest rate realized by the individual - an increase in the value of assets held for the future relative to the present. How much of a change in interest rates the NSB account represents depends on both the manner in which the individual was previously saving - for example, in cash, in livestock, or in business inventories - and on how secure those savings were. Cash savings, for example, may be subject to loss from theft, personal temptation, or capture by others. In that case, the effective interest rate on cash savings might be negative, and the change in interest rate arising from the NSB account might be quite large and positive. We develop a simple framework which analyzes how the participants should be expected to respond to a change in interest rates. The model takes into account the mixed nature of our sample - wage workers and self-employed, and allows for changes in both the labor supply and consumption, within and across periods.

A literature in macroeconomics considers the way in which the labor supply responds to shifts in wages and interest rates across the business cycle (Lucas and Rapping, 1969). We apply a

\footnotetext{
${ }^{9}$ We used randomization inference techniques (Small et al. 2008) to re-run our randomization code 1,000 times and examine how the actual sub-group balance of our experiment compares to the distribution of subgroup treatment/control differentials that could have obtained given our sample and randomization routine. This illustrates that we were simply unlucky in realizing a group of treatment females (males) that are substantially richer (poorer) than the control ( $\mathrm{p}$-value $<.01$ for highly imbalanced variables such as household income among males).

10 Interestingly, if we use only the data from the round 1 survey (on which the stratification was conducted), no significant signs of sub-group imbalance are observable. The imbalances result from a gap that opens up between treatment and control within men and within women in rounds 2-5, and hence is only observable because we went to the trouble of collecting multiple high-frequency pre-treatment surveys as suggested by McKenzie (2012).
} 
model of the intertemporal substitution of leisure in Blanchard and Fischer (1989) to the question of how labor responds when a mixed sample of micro-entrepreneurs and wage workers are confronted with an intervention that increases the return on savings. We focus initially on a model without capital investment, because we want to highlight the effect of a change in interest rates on the intertemporal substitution of labor and leisure. We return later to the implications of including capital.

Consider a two-period model in which $c_{t}$ gives consumption in each of the two periods $t$, $\theta$ is a discount rate, and $\sigma$ gives the elasticity of substitution of labor across periods. The model also allows for variation in the marginal value of leisure relative to consumption, represented by a parameter $\gamma$. Agents can put their work time into the wage labor market $x_{t L}$ with a fixed hourly wage $w$ or into a microenterprise with per-period returns to own labor $f\left(x_{t M}\right)$ that are increasing and concave in microenterprise time $x_{t M}$. The two types of work are perfect substitutes in terms of the disutility of labor. Agents will maximize utility:

$$
U\left(c_{1}, c_{2}, x_{1 L}, x_{2 L}, x_{1 M}, x_{2 M}\right)=\sum_{t=1,2}(1+\theta)^{-(t-1)}\left[\ln c_{t}-\left(\frac{\gamma \sigma}{\sigma+1}\right)\left(x_{t L}+x_{t M}\right)^{(\sigma+1) / \sigma}\right]
$$

subject to the budget constraint:

$$
c_{1}+\frac{c_{2}}{1+r} \leq w x_{1 L}+f\left(x_{1 M}\right)+\frac{w x_{2 L}+f\left(x_{2 M}\right)}{1+r} .
$$

To maximize returns within a period agents will invest labor time in microenterprise until $f^{\prime}\left(x_{t M}\right)=w$. Those able to achieve this as an interior condition will be both on the labor market and working in microenterprises - something that is fairly common in our sample. Those for whom $f^{\prime}(0)<w$ will do only wage work, and those for whom the marginal return to self-employment is higher than the wage rate even at the maximum number of labor hours $-f^{\prime}\left(x_{t M}^{\max }\right)>w-$ will work solely in microenterprises.

Agents doing any wage work will always consider the wage job on the margin, since labor time in the microenterprise is nailed down by the wage. In this case, the ratio of labor inputs in the first and the second period is:

$$
\frac{x_{1}}{x_{2}}=\left(\frac{1+r}{1+\theta}\right)^{\sigma}
$$


which is increasing in the interest rate. For agents not doing any wage work the opportunity cost of leisure is defined by microenterprise returns, and so we have the analogous expression:

$$
\frac{x_{1 M}}{x_{2 M}}=\left[\left(\frac{f^{\prime}\left(x_{1 M}\right)}{f^{\prime}\left(x_{2 M}\right)}\right)\left(\frac{1+r}{1+\theta}\right)\right]^{\sigma} \text {. }
$$

This expression is similar to (3) but displays an additional impediment to the substitution of labor across periods since $f^{\prime}($.) is itself concave (as well as time preferences in leisure). This implies that intertemporal wage labor decisions will be more strongly affected by shifts in the interest rate than will intertemporal labor decisions in microenterprises.

This simple theoretical environment allows us to characterize expected changes on both the extensive and intensive margin in response to an increase in the savings interest rate. As the future value of income earned in the first period increases, optimal initial labor inputs will rise. Because the returns to labor are constant on the wage market and declining in self-employment, this change will alter both the intensive margin (hours worked for wage and in microenterprises) and the extensive margin (the fraction of the sample that chooses to work for a wage, and chooses to engage in microenterprise).

i. On the extensive margin,

a. Some individuals who had not previously been willing to do wage work should enter the wage workforce.

b. Some individuals who had previously been working in both micro-enterprise and wage labor should exit self-employment.

ii. On the intensive margin

a. Paid wage labor should (weakly) increase for everyone.

b. Microenterprise labor should increase for those who remain specialized in it.

c. For those who do both microenterprise and wage work, microenterprise labor should decrease.

d. The marginal response of microenterprise labor should be smaller than the marginal response of wage labor because the production function is concave.

e. Consumption will decrease in period one but increase in later periods. However, expenditure may increase even in period 1, as individuals purchase durable goods anticipating higher levels of consumption in the later period. 
Our framework abstracts entirely from capital investments. A neo-classical treatment of capital would see forces pulling investment in opposite directions. One is immediate: as the concave returns to investment are confronted with a higher bank savings rate, entrepreneurs would wish to disinvest in businesses and put capital into savings instead. That is, if investment in the business is equated to the rate of interest in savings, then the increase in the savings interest rate will lead to disinvestment. Over the longer term, however, an increase in business scale could occur if there are indivisible investment opportunities with high returns, and the more rapid accumulation of savings enables enterprise owners to make lumpy investments. Assuming labor and capital are complements, the short-term disinvestment would reinforce the withdrawal from self-employment predicted by the labor-only model, while the benefits of the longer-term lumpy investments could reverse the decline in time spent working self-employed. In either case, the capital-driven mechanism would suggest that income should increase only over the longer term.

\section{RESUlts.}

The changes in labor supply and intertemporal consumption that come from the model are driven by an increase in the interest rate on savings. If the collection services did increase the effective interest rate realized by program participants, then we should observe both a robust takeup of the product, and an increase in total savings. These outcomes are the equivalent of a first stage in the experiment. We begin, then, by looking at these preliminary outcomes.

\subsection{Uptake and Usage.}

Table 1 uses pre-treatment averages (data from rounds 1-5) to predict subsequent uptake and usage of the accounts among the 389 individuals offered the treatment. Account usage appears progressive in that those most likely to make any deposit are low-income females who score poorly on the digitspan test, but at the same time a strong predictor of use of our accounts is a history of formal savings prior to the initiation of the experiment. Low-expenditure households use the accounts most frequently for both deposits and withdrawals, but none of our determinants are significant in explaining the total number of transactions in program accounts. Among those who make deposits the two significant determinants of the log of deposits are having more education and having higher formal savings at baseline. Those with high baseline savings also make significantly more withdrawals from program accounts, however, leading to final savings balances that are not significantly higher than those who had no formal savings at baseline. Final savings balances are 
strongly progressive in expenditures (meaning that poor households save significantly more through the program than wealthier households even in absolute terms), and baseline seetu participation is also predictive of lower final savings balances. The progressivity of final savings balances is encouraging, indicating that weekly home visits with the POS terminals are particularly effective at generating deposits from low-income households.

\subsection{Savings impacts.}

The weekly visits to households generate a large increase in the frequency of transactions with formal financial institutions; Table 2 indicates that these quadruple from a control average of .5 transactions per month to a treatment average of over 2 per month. The dramatic nature of this effect is depicted in Figure 2. Despite a large increase over the control group, the data show that treatment households only make deposits through the collectors about half of the time. The institutional data (Column 3) indicate that net savings in the NSB accounts linked to the project increase by $425 \mathrm{LKR}$ per month. The survey data (Column 5) indicate that total bank savings increase by roughly 690 LKR per month. On the surface, this implies that the treatment also leads to an increase in deposits in other formal accounts. While we would be cautious about that conclusion - not least because the difference of 265 LKR per month is not significantly different from zero, but also because the survey data may be noisier - the data at least suggest that the NSB savings are not coming directly from other formal savings accounts. Indeed, the remaining columns on Table 2 indicate that informal savings increase by a nominal (and insignificant) amount, and that total savings through all vehicles increase by 883 LKR per month as a result of the treatment. Panel B shows that this amount remains quite constant across the course of the study, at least until the very last round two years following the initial treatment. The increase in total savings flows of $883 \mathrm{LKR}$ monthly is around 4 percent of the mean personal income in the sample.

This preliminary look at savings therefore indicates that treatment leads to a statistically significant and economically meaningful increase in total savings by the individual. There is no evidence that the savings deposited in the NSB account is crowding out either other formal savings or informal savings. The increase in savings suggests that participants viewed the collection services as a substantial change in their portfolio of financial services, opening the possibility that the treatment led to more fundamental changes in their behavior. 


\subsection{Headwaters.}

Tables 1 and 2 show that the experiment has the effect of increasing the aggregate savings of the participants. This allows us to ask the central question for which the experiment was designed: Where does the increase in savings come from? The three immediate possibilities are: 1) a reduction in expenditures; 2) an increase in earned income; 3) and increase in net transfers from others inside or outside the household. Previous research gives some support for at least the first two possibilities. Banerjee et al (2013) find that microfinance clients investing in microenterprises reduce expenditures on 'temptation goods' and increase the purchase of durable goods. And both Dupas and Robinson (2012) and Prina (2013) find that expenditures increase with the introduction of savings products which are similar to the one we implement. Though neither of these papers reports data on income, the implication is that incomes of those offered the accounts have increased. While Dupas and Robinson focus on the possibility of savings allowing account holders to make lumpy investments or to protect investable balances from themselves or sharing networks, our theory suggests an alternative channel: an intertemporal rebalancing of effort driven by an increase in effective interest rates.

Our high frequency data focused on the cash flow of the individual participants allows us to present a very detailed view on this question. We begin with an analysis of the flows on Table 3. We exploit the final part of the household survey in which we conduct an accounting exercise whereby respondents are asked to calculate their personal incomes, intrahousehold transfers, and personal expenditures to arrive at a final total monthly savings amount through all formal and informal vehicles. Table 3 presents treatment effects on these aggregated variables, taken from an ITT regression with individual and time period fixed effects. The data are strongly suggestive of the idea that increases in income are the source of savings balances. Personal and household income both surge in the months following the introduction of the treatment. We have the most confidence in the individual savings, expenditures, and income figures since these are best known to the individual survey respondent. Looking at the first four-month period in Table 3, we see that the increase of almost 1,000 LKR per month in personal savings and a simultaneous increase of almost 1,200 LKR per month in the in personal expenditures plus transfers to others is explained by the fact that individual income plus transfers from others goes up by just under 2,500 LKR per month. Household income increases by an even more substantial amount, 3,466 LKR per month over the first four months of treatment and by almost 2,500 $9-13$ months following treatment. This suggests that the solution to the puzzle of the headwaters of formal savings is to be found in 
understanding how households and individuals were able to generate substantial increases in income when offered a new savings vehicle.

\subsection{Income Source.}

How are the immediate increases in household and personal income from Table 3 achieved? One possibility which has been suggested by the literature is that savings accounts relax a credit constraint for microeneterprise owners, perhaps because they allow owners to aggregate savings to make lumpy investment. (See, for example, the discussion in Dupas and Robinson 2012.) Because we have monthly income and expenditure data, we are able to test this possibility directly. As Figure 3 shows, the increase in income follows immediately after the start of the savings program. The time before the effect is realized is implausibly short for the save-invest-earn dynamic to be driving the increase in income. ${ }^{11}$

The theory outlined in Section 3 suggests an alternative channel. In the model, increases in the interest rate on savings result in increases in desired labor effort during a period in which savings balances are being accumulated. The model generates several testable predictions, which we examine more closely in Table 4. First, the theory predicts an increase in labor effort, more robustly among wage workers than among the self-employed. The leisure-for-labor substitution is driven by the increase in the value of labor in terms of period 2 consumption. Second, the theory predicts some shift from self-employment to wage work, at the margin. This substitution is driven by the combination of the desire to increase labor effort, the linearity of returns to wage work, and the decreasing returns to self-employment. Thus, a third prediction is that those nearest the margin of the choice between self-employment and wage work should be the most likely to shift out of selfemployment.

The first three columns of Table 4.1 examine the effect of treatment on hours worked, income earned by the individual respondent and a dummy indicating the individual is self-employed. For the full sample of participants, we find an insignificant increase in the number of hours worked, but a significant increase in earnings. We explore this seeming contradiction in more detail below.

\footnotetext{
${ }^{11}$ In Appendix Table 4, we exploit the extraordinarily precise monthly data to give much more detail on the sources and uses of household cash from sources other than income. We present the results of this accounting exercise by first showing simple regression coefficients in Column 1 and standard errors in Column 2, and then in Column 3 we translate these coefficients into changes in the cash balance of the individual by giving a positive sign to incoming liquidity flows and a negative sign to outgoing liquidity flows. Savings through all informal vehicles actually increases by 652 LKR per month, indicating less liquidity from informal savings as well. Withdrawals and loans both fall by very small amounts, consumption and loan repayment increases, all indicating less liquidity. Only via transfers from others (spouses and individuals outside the household) is liquidity increased at all.
} 
Consistent with the theory, we also find (column 3) a decrease in the rate of self-employment. Just over 52 percent of households in the treatment group reported being self-employed in round 2; this fraction drops by 3.4 percentage points during the duration of the treatment.

In Columns 4-7 of Table 4.1, we examine labor hours and earnings for individuals who were not self-employed in at least one pre-treatment round. This subsample includes the individuals who switch back and forth between wage work and self-employment, and so have demonstrated the greatest ability to substitute into wage work. For this group we see a significant increase in the hours worked in wage work, an insignificant decrease in the hours worked in self-employment, and insignificant increase in both wage earnings and total earnings. Given that Column 3 shows that the net switch is out of self-employment, the pattern of hours is not surprising. However, the patterns are consistent with the prediction of the model.

Table 4.2 examines the source of increases in income among those who reported being selfemployed in every pre-treatment round. Columns 1 and 2 show that while there is an increase in hours worked in both self-employment and wage work among this group, neither of these effects is statistically significant. However, business sales jump immediately after the treatment begins and monthly self-employment income rises, accounting for fully half of the total increase in personal income. The income results are consistent with self-employed individuals exerting higher effort and achieving more sales as a result (while the hours the business operates may not change, the effort exerted in making sales might). This surge in sales is not accompanied by a corresponding restocking, meaning that the total value of treatment inventories decreases steadily over time, consistent with an adjustment of marginal returns to higher interest rates. The value of business fixed assets is lower in the treatment than the control in every round but the very last, suggesting that that if increased sales or savings balances are being translated into fixed capital investment that happens beyond the 24 -month window of our study. ${ }^{12}$

Tables 4.1 and 4.2 show several patterns consistent with the predictions of the model. First, we find a modest but persistent shift out of self-employment into wage work. Second, we find an adjustment of labor hours and effort, but not of fixed capital investments. Average hours worked in wage jobs also increase. While we find no significant increase in hours worked in self-employment, there is a suggestion of increased effort there, as revenues and profits initially increase even though

\footnotetext{
12 Note that unlike us, both Dupas and Robinson (2012) and Schaner (2013) do find that savings programs lead to higher capital investments in different samples of Kenyan microenterprises. Dupas and Robinson select a sample of selfemployed individuals, but Schaner's sample is mixed with regard to employment. She finds a net entry into selfemployment, a finding clearly distinct from what we find.
} 
neither hours worked nor business assets increase. Finally, we find these adjustments and an increase in income occurring immediately after the savings collections begin. In the next section, we consider the alternative channels through which savings might increase household income.

\section{Alternative EXPLANATiONS}

While our focus is on the allocation of time across labor and leisure, and wage work and selfemployment, the literature has focused more attention on the effect of savings on lumpy investments - an issue we discussed above - and overcoming commitment problems. We do not see these as competing explanations so much as alternative channels of impact. Indeed, they could be complementary in the sense the labor response to an increase in the effective interest rate may create (and even be motivated by) opportunities to eventually increase entrepreneurial activity. It may be that savings affects income and expenditure through multiple channels, and that these channels are differentially important in different populations. We read the evidence presented in the previous section as showing that the labor allocation channel - largely overlooked in the literature to date - is important. That is the main conclusion of our analysis. In this section, we examine the extent to which other channels add to the explanation of the outcomes.

\subsection{Self-Control and Spousal Control}

Much of the recent interest in the theory underlying the use of savings products has been due to behavioral economics' focus on the difficulty that people have in achieving their own savings goals if money must be put aside out of daily cash flows. Several very distinct motivations for under-saving have emerged, but each suggests that a high-frequency deposit collection service can alter consumption in important ways. Individuals with self-control problems will achieve a higher savings trajectory if the long-term self can lock the short-term self into a commitment (Laibson 1997). Frequent deposit collecting allows people to get loose cash away from themselves and may permit them to control their own consumption of 'temptation goods' (Banerjee and Mullainathan 2009). When members of a household disagree on the optimal savings trajectory, private commercial savings may allow the pro-savings individual in the household to control the household savings rate (Andersen \& Baland 2002). Our savings product provides an interesting window on these behavioral dimensions: it features convenient deposit and inconvenient withdrawal (individuals still had to travel to town to take money out of the accounts) and therefore has a commitment dimension. 
Accounts are in the name of the core respondent and provide a potentially confidential environment for savings, and thus may also change intrahousehold bargaining.

The fact that the treatment increases expenditures suggests that none of these arguments about controlling consumption can be playing a driving role in the overall effects of the program. When household and personal income go up by more than $10 \%$, controlling consumption may become less important, not more so. Nonetheless, the improved control offered by the deposit collecting should generate heterogeneity in the changes in consumption and savings that occur as the program is introduced. In order to understand this heterogeneity, we examine how the effects of the program on expenditures, intrahousehold transfers, and savings differ with measures of time inconsistency of the participant.

We measure time inconsistency in the standard way; our baseline survey asks households "Suppose someone was going to pay you Rs. 15001 month from now. He/she offers to pay you a lower amount today. What amount today would make you just as happy as receiving Rs. 1500 in 1 month?" The answer to this question gives the total current discount factor, or the product of beta and delta if intertemporal preferences take the quasi-hyperbolic form $U=E_{0}\left[u\left(c_{0}\right)+\beta \sum_{t=1}^{T} \delta^{t} u\left(c_{t}\right)\right]$.

We then ask the same question with the time scale moved out by one year (12 months from now versus 13 months), and the beta parameter can be calculated by the ratio of the former to the latter answer. For clarity of interpretation we use the inverse of the beta parameter, a quantity increasing in the degree of time inconsistency, and we demean this variable prior to the interaction so that the uninteracted treatment effect gives the impact at the average rate of time inconsistency.

Because of the special role of deposit collecting in potentially controlling the consumption of 'sin' or 'temptation' goods, we conducted a panel survey experiment to induce truthful revelation of goods whose use may be stigmatized. The survey experiment asked respondents to pick (and not reveal to the enumerator) cards numbered from 1 to 10 prior to each question about consumption of different sin goods. If the number was between 4 and 10 the respondent was to answer 'blue' if they consumed that sin good in the past month and 'red' if not, but if the number was between 1 and 3 they were to answer 'blue' regardless of the correct response. In this way enumerators can never infer the consumption status of a specific individual, but the sample prevalence of sin good consumption can be readily calculated. The same property of aggregation holds across sin goods for 
an individual; consequently the panel dependent variable used in the analysis is $\frac{\sum_{j} I_{j}\left(\text { blue }_{j}\right) / J-.3}{.7}$, where $I_{j}\left(b_{l u e_{j}}\right)$ is an indicator for a response of 'blue' for each of the $J$ sin goods in the survey experiment. We asked about purchase of alcohol, purchase of tobacco, and about gambling on horse races and on cards. These questions were asked in pre-treatment wave 3 and in posttreatment waves 10 and 18 .

Table 5 examines the heterogeneity of treatment effects by the extent of time inconsistency. There is no evidence of heterogeneous program effects on the measure of overall household or individual expenditures (Columns 1 and 3), or on the survey experiment measure of consumption of sin goods (Column 5). Indeed the program overall appears to have little effect on the fraction of sin goods consumed. The point estimates of the interaction effect on all the self-reported expenditures categories are negative, consistent with the idea that deposit collection has been most effective at helping those with time inconsistent preferences to avoid spending money on consumption, but these effects are not significant. For savings behavior, however, we see quite strongly heterogeneous effects. Interestingly, not only do hyperbolic discounters see a particularly large increase in the number of financial transactions overall, but this heterogeneity is particularly marked for non-program transactions (Columns 6 and 7). The same pattern is present in total non-bank savings, and the implication is that the significant heterogeneity in total savings observable in the final column is largely due to the fact that the treatment helps hyperbolic discounters increase their use of informal savings vehicles. Hence the analysis of heterogeneity over time inconsistency again underlines a peculiar form of complementarity between formal and informal savings: those who have the most difficult time executing their own savings goals find formal deposit collecting particularly useful in expanding the use of both formal and informal savings.

\subsection{Effect on use of commitment savings: the seetu saturation experiment}

The core purpose of the seetu saturation experiment is to examine whether formal savings undermine the personal savings networks that often form the backbone of informal insurance. The most dramatic evidence of this would be seetu collapse, but given the relatively short duration of our study and the small number of seetus involved in the experiment, we are unlikely to find significant differences in the rate of collapse across the saturation experiment. We therefore concentrate on the number of seetus in which members participate as a measure of the extensive margin of informal 
savings, and the total amount saved through seetus monthly as a measure on the intensive margin. To understand the impact of seetu saturations on informal insurance, we use the monthly flows of transfers into the household and out of the household (we screened out cases in which a second household member was in the same seetu as the respondent, and so the interpersonal flows of informal insurance should be primarily inter-household). We also examine the effect of the seetu saturation experiment on overall savings. The sample for this analysis consists of the sampled $20 \%$ of the membership of each of the 84 close seetus drawn into the survey at baseline.

We use two empirical specifications for each outcome. The first examines the overall intention-to-treat effect within the close seetu membership. The second includes a dummy for treatment and further includes the randomly chosen saturation within treatment seetus. In this specification the dummy for treatment gives the impact in the $20 \%$ treatment saturation seetus, and the slope term on the saturation gives the marginal effect on outcomes of treating (but not studying) an additional fraction of the membership beyond this. Because we have no individuals that are studied but not treated in treatment seetus, we are only able to estimate the Spillover on the Treated, and not the Spillover on the Not Treated (Baird et al., 2014). The effects of the saturation should therefore be interpreted as the impact of increasing the fraction of the seetu given the deposit collection treatment, conditional upon the fact that the studied individual is treated.

Before presenting the results of this analysis, Appendix Table A6 shows the balance of the seetu saturation experiment. This randomization was conducted in a very small number of units; the saturation experiment is particularly subject to potential imbalance as each saturation cell contains only 13 seetus. We show balance over 15 tests and find only one of them to be significant at the $10 \%$ level, but nonetheless there are some quantitatively large differences, particularly across the saturation amounts within the treatment. Overall savings is imbalanced across the distribution of the saturation. We therefore proceed to the analysis of the saturation experiment with some caution as the number of assignment units is small and the balance not perfect.

The results of this analysis are given in Table 6. Contrary to the hypothesis that private individualized savings poses a threat to seetu participation, the treatment and the treatment saturation appear to lead to superior outcomes for the seetu. Treatment on average increases the number of seetus in which a respondent participates by 0.293 over a base of 2 , an increase of more than 10 percent. Allowing for heterogeneity across the saturation rate indicates that where more individuals are treated, membership in seetus increases more rapidly. The coefficient of 1.435 , significant at the $1 \%$ level, indicates that each $20 \%$ increase in the fraction of the seetu treated 
increases the number of seetus participated in by its members by a further .3. The monthly amount saved through seetus is higher in treatment than control zones, and the saturation effect is again positive and large in absolute magnitude although not significant.

Finally, looking at informal insurance issue, we find that the saturation experiment has no significant effects - and, indeed, the point estimates on the saturation experiment are positive - on transfers into and out of the household.. The transfers coming into the household are perhaps most meaningful given the nature of the experiment: all of the studied individuals in the saturation experiment are themselves treated, and so if the increase in the treatment saturation were having a detrimental effect on the quality of social insurance then we would expect transfers to these treated individuals to be declining. This does not appear to be the case, and so we find no evidence of a deterioration in informal insurance as a result of the intensity of access to formalized individual savings products. The total amount saved is $940 \mathrm{LKR}$ per month higher in treatment than control seetus, not quite significant at the $10 \%$ level, and the coefficient on the saturation is again positive. Hence, the result of the randomized saturation experiment indicates that far from posing a threat to them, the bank-driven deposit collecting appears to be fortifying informal savings groups.

\section{ConClusion.}

We conducted an experiment with a powerful inducement to save: weekly visits by a deposit collector equipped with a wireless POS device capable of printing out account balance receipts on the spot. The experiment was implemented in Sri Lanka, a country with strong informal savings institutions and a tradition of using formal banks for 'children's accounts' into which parents often begin to save at the birth of a child. Despite this, we find strong effects of the treatment not just on savings into program accounts, but into bank savings and overall savings as a whole. We tracked the sample with a state-of-the-art data collection instrument; monthly surveys including five pretreatment waves, and a careful cash-flow accounting instrument designed to answer two questions. First, what are the headwaters of formal savings? Second, what are the channels through which formal savings affects income and expenditures?

The surveys reveal that the source of the liquidity newly flowing into formal savings is an increase in income driven largely by increases in labor effort rather than forgone expenditures or a change in intrahousehold transfers. In one sense it is surprising that a financial service offering nothing more than a low-cost means to save in a bank could increase household income. However, as Blanchard and Fischer showed long ago, the responses we observe in the data are consistent with 
those we would expect from individuals who experience a large increase in the interest they receive on savings. The data then suggest that, in spite of the sample having access to a wide range of formal and informal savings mechanisms, the simple low-transactions cost account represented a significantly better option.

The model shows that an increase in the interest rate increases desired future consumption relative to current consumption, and causes individuals to increase labor effort in the initial period, in order to build up savings. Given diminishing returns to labor in self-employment, and constant returns to labor in wage work, the increase in labor hours is expected to be accompanied by a shift out of self-employment into wage work. The data support both of these predictions. We find that the treatment triggers exit to increase by almost 8 percent of the self-employed (4 percentage points off a baseline average of 51\%), and an increase in the number of hours in wage work. Moreover, we find an increase in the income earned by the self-employed. Given that neither hours worked nor capital employed in the business increase, this suggests that the effort level of the self-employed may have increased.

The labor channel has largely been ignored in the literature on savings programs. We read the results here as suggesting we should be paying more attention to it. However, there are a couple of characteristics of our setting and sample that may not be replicated in every setting. First, many of our wage workers work as daily paid workers. They may have more flexibility to adjust hours worked than wage workers in longer-term work relationships. Daily paid wage work is not uncommon in low-income countries, but neither is it the most common form of wage work everywhere. Second, our impression from conversations with various participants in the program is that Sri Lankans are quite sophisticated financially, and quite numerate. Education levels are high, given the rural nature of the sample, averaging 10 years. Perhaps the response to these changes is more robust than it would be in populations with lower formal schooling and numeracy skills.

We do not want to claim that the labor channel is the only way that savings may affect outcomes related to expenditures and outcomes. But in our data, it appears to be the main channel. We find no evidence supporting a role for enabling capital investments, and only a weak association with time inconsistency - often a trigger for behavioral explanations of savings program effects. Moreover, the increase in income over the course of the study is directed towards formal savings, expenditures, and also towards informal savings. Indeed, this individualized formal financial product appears to promote participation in informal savings vehicles in a number of interesting ways. Within the sample participating in seetus at baseline, treatment results in a sharp increase in 
the number of seetus they use over time, and a weak increase in the amount of money they save through seetus. An increase in the randomized fraction of members offered the treatment appears to further increase seetu usage, indicating that the treatment not only enables personal participation in informal savings groups but confers a positive network externality on this participation.

Our study is subject to a number of limitations. First, while the sample size for the study is relatively large, the number of units over which the randomization was conducted is more modest, and the study suffers from some sub-group imbalance problems, particularly with respect to gender. We have discussed the imbalance explicitly where it is visible and attempted to stay away from imbalanced subgroup analysis. Also, while many comparable papers study the extension of marketable savings products, we intentionally used a very intense impetus to savings in order to study the headwaters question. We show in a companion paper that when the deposit collection product is modified to be more commercially viable it has little effect on the bank savings with NSB, but the program no longer increases overall savings (de Mel et al 2013). In this sense we are studying an impetus to save that may be considered unnaturally strong, and the near-term expansion of more financially viable pro-poor savings products (such as community deposit boxes or mobile money) is unlikely to provoke as strong a response in income and overall savings as observed here.

An alternative to the type of high-frequency forensic accounting used in this paper is simply to ask beneficiaries what has changed in their households and how these changes were achieved. In the final wave of the survey we implemented such a module in the treatment group, and the answers are very consonant with the overall analysis. 93\% of respondents say they are saving more as a result of the program, with the most common stated source of the money being increased income (38\%), followed by reduced consumption (33\%) and increased transfers from others in the household $(22 \%)$. When asked how these income increases are achieved, by far the most common answer is that they 'made more effort to increase production/sales in self-employment' (59\%), followed by 'worked more in permanent/casual work' (13\%), and only 12\% report investing more in entrepreneurship. Both forms of analysis therefore agree that the income increases are not the result of the savings having permitted a high-investment business trajectory, but rather that the desire to save induced subjects to undertake additional effort in order to increase income. In our context, it therefore appears that rather than the savings being an instrument towards improved business outcomes, the savings are the end in themselves and entrepreneurs are redoubling efforts in their businesses in order to generate the savings. 
We conclude by reflecting on the fact that a treatment offering nothing but an additional inducement to generate liquidity led to large enough increases in income that savings and expenditures could both go up at the same time. This suggests that financial service innovation can have a major effect on the incentives for the poor to escape poverty. 


\section{BIBLIOGRAPHY.}

Anderson, Siwan, and Jean-Marie Baland. 2002. "The Economics of Roscas and Intra-household Resource Allocation.” Quarterly Journal of Economics, 117(3): 963-995.

Ashraf, Nava. 2009. "Spousal Control and Intra-Household Decision Making: An Experimental Study in the Philippines." American Economic Review 99, no. 4: 1245-1277.

Ashraf, Nava, Dean Karlan, and Wesley Yin. 2006. "Tying Odysseus to the Mast: Evidence from a Commitment Savings Product in the Philippines." Quarterly Journal of Economics, 121(2): 635672.

Atkinson, J., A. de Janvry, C. McIntosh, and E. Sadoulet. 2012. "Prompting Microfinance Borrowers to Save: A Field Experiment from Guatemala." Economic Development and Cultural Change.

Attanasio, O., and J.V. Rios-Rull. 2000. "Consumption Smoothing in Island Economies: Can Public Insurance Reduce Welfare?” European Economic Review (44): 1225-1258.

Baird, S., Bohren, A., McIntosh, C., and Ozler, B. (2014). "Designing Experiments to Measure Spillover and Threshold Effects." Working paper.

Duflo, E., Banerjee, A., Glennerster, R., \& Kinnan, C. G. (2013). "The miracle of microfinance? Evidence from a randomized evaluation” (NBER WP 18950). National Bureau of Economic Research.

Banerjee, Abhijit, and Sendhil Mullainathan. 2009. "The Shape of temptation: Implications for the Economic Lives of the Poor.” Mimeo, Economics Department, MIT.

Banerjee, A. V., \& Newman, A. F. (1993). Occupational choice and the process of development. Journal of Political Economy, 274-298.

Bauer, M., J. Chytilova, and J. Morduch. 2008. "Behavioral Foundations of Microcredit: Experimental and Survey Evidence from Rural India." Working Paper.

Bertrand, M., E. Duflo, and S. Mullainathan. 2004. "How Much Should we Trust Difference in Differences Estimates?” Quarterly Journal of Economics, 119(1): 249-275.

Blanchard, O. J., \& Fischer, S. (1989). Lectures on macroeconomics. MIT press.

Brune, L., X. Gine, J. Goldberg, and D. Yang. 2011. "Commitments to Save: A Field Experiment in Rural Malawi." World Banking Policy Research Working Paper 5748.

Coate, S., and M. Ravallion. (1993). "Reciprocity Without Commitment: Characterization and Performance of Informal Insurance Arrangement.” Journal of Development Economics (40): 1-24.

Collins, Daryl, Jonathan Morduch, Stuart Rutherford, and Orlanda Ruthven. 2009. Portfolios of the Poor: How the World's Poor Live on $\$ 2$ a Day. Princeton University Press. 
Crepon, Bruno, Esther Duflo, Marc Gurgand, Roland Rathelot, and Philippe Zamora. (2013). "Do Labor Market Policies have Displacement Effects? Evidence from a Clustered Randomized Experiment." The Quarterly Journal of Economics, 128(2): 531-580.

de Mel, S., C. McIntosh, \& C. Woodruff (2013). "Deposit Collecting: Unbundling the Role of Frequency, Salience, and Habit Formation in Generating Savings." American Economic Review, Papers and Proceedings.

de Mel, S., D. McKenzie \& C. Woodruff (2008). "Returns to Capital in Microenterprises: Evidence from a Field Experiment," The Quarterly Journal of Economics 123(4): 1329-1372,

Deaton, Angus (1991). "Saving and Liquidity Constraints." Econometrica, September 1991, 59(5), pp. $1221-48$.

Demirguc-Kunt, A., \& Klapper, L. (2012). Measuring financial inclusion: The global findex database.

Dercon, Stefan. "Risk, crop choice, and savings: Evidence from Tanzania." Economic development and cultural change (1996): 485-513.

Dupas, Pascaline, and Jonathan Robinson. 2013. "Savings Constraints and Microenterprise Development: Evidence from a Field Experiment in Kenya." American Economic Journal: Applied Economics, Vol. 5 (1), pp. 163-192.

Dupas, Pascaline, and Jonathan Robinson. 2012b. “Why Don’t the Poor Save More? Evidence from Health Savings Experiments.” Working Paper.

Gugerty, M.K. (2007). "You Can't Save Alone: Commitment in Rotating Savings and Credict Associations in Kenya." Economic Development and Cultural Change 55(2): 251-282.

Karlan, D., M. McConnell, S. Mullainathan, and J. Zinman. 2010. "Getting to the Top of Mind: How Reminders Increase Saving." NBER Working Paper 16205.

Laibson, David. 1997. "Golden Eggs and Hyperbolic Discounting." Quarterly Journal of Economics, 112(2): 443-477.

Lucas, R. E., \& Rapping, L. A. (1969). "Real wages, employment, and inflation." The Journal of Political Economy, 721-754.

McKenzie, David (2012). "Beyond Baseline and Follow-up: The Case for more t in Experiments," Journal of Development Economics, Vol. 99 (2), pp. 210-221.

O’Donoghue, Ted, and Matthew Rabin. 2001. "Choice and Procrastination." Quarterly Journal of Economics, 116(1): 121-60.

Prina, S. (2013). Banking the poor via savings accounts: Evidence from a field experiment. Case Western Reserve University, Weatherhead School of Management Working Paper, available at: http://faculty.weatherhead.case.edu/prina/pdfs/prina_savingsaccounts_2013.pdf 
Samphantharak and Townsend (2009). Households as Corporate Firms, Cambridge: Cambridge University Press.

Schaner, S. (2013). The Persistent Power of Behavioral Change: Long-Run Impacts of Temporary Savings Subsidies for the Poor. Dartmouth College Working Paper, available at: http://www. dartmouth.edu/ sschaner/main_files/Schaner_LongRun.pdf.

Small, Dylan, T. Ten Have, and P. Rosenbaum. (2008). "Randomization Inference in a GroupRandomized Trial of Treatments for Deptression: Covariate Adjustment, Noncompliance, and Quantile Effects." Journal of the American Statistical Association, 103(481).

Thaler, Richard, and Shlomo Benartzi. 2004. "Save More Tomorrow (TM): Using Behavioral Economics to Increase Employee Saving." Journal of Political Economy 112(S1): S164-S187. 


\section{TABLES}

Table 1. Determinants of Uptake and Product Usage

Determinants of Uptake and Product Usage.

\begin{tabular}{|c|c|c|c|c|c|c|}
\hline Baseline Characteristics: & $\begin{array}{c}\text { Made Any } \\
\text { Deposit }\end{array}$ & $\begin{array}{c}\text { Made Any } \\
\text { Withdrawal }\end{array}$ & $\begin{array}{l}\text { Total Number } \\
\text { of } \\
\text { Transactions }\end{array}$ & $\begin{array}{c}\text { Log of } \\
\text { Monthly } \\
\text { Deposits } \\
\text { (if any) } \\
\end{array}$ & $\begin{array}{c}\text { Log of } \\
\text { Monthly } \\
\text { Withdrawals } \\
\text { (if any) } \\
\end{array}$ & $\begin{array}{c}\text { Log of } \\
\text { Final } \\
\text { Balance } \\
\text { (if any) }\end{array}$ \\
\hline Female & $\begin{array}{c}0.0579^{*} \\
(0.03)\end{array}$ & $\begin{array}{c}-0.0241 \\
(0.06)\end{array}$ & $\begin{array}{l}1.711 \\
(1.54)\end{array}$ & $\begin{array}{c}-0.197 \\
(0.21)\end{array}$ & $\begin{array}{c}-0.0138 \\
(0.30)\end{array}$ & $\begin{array}{c}0.0527 \\
(0.20)\end{array}$ \\
\hline Years of Education & $\begin{array}{c}0.00 \\
(0.00)\end{array}$ & $\begin{array}{c}0.01 \\
(0.01)\end{array}$ & $\begin{array}{l}0.124 \\
(0.22)\end{array}$ & $\begin{array}{c}0.0564 * \\
(0.03)\end{array}$ & $\begin{array}{c}0.05 \\
(0.05)\end{array}$ & $\begin{array}{c}0.01 \\
(0.03)\end{array}$ \\
\hline Self Employed & $\begin{array}{c}0.0623 \\
(0.04)\end{array}$ & $\begin{array}{c}0.0307 \\
(0.06)\end{array}$ & $\begin{array}{l}2.165 \\
(1.81)\end{array}$ & $\begin{array}{l}0.382 \\
(0.25)\end{array}$ & $\begin{array}{l}0.143 \\
(0.39)\end{array}$ & $\begin{array}{l}0.375 \\
(0.24)\end{array}$ \\
\hline Employed in Agriculture & $\begin{array}{c}0.01 \\
(0.05)\end{array}$ & $\begin{array}{c}-0.02 \\
(0.06)\end{array}$ & $\begin{array}{l}-0.102 \\
(1.86)\end{array}$ & $\begin{array}{l}-0.104 \\
(0.25)\end{array}$ & $\begin{array}{l}-0.07 \\
(0.44)\end{array}$ & $\begin{array}{c}0.07 \\
(0.25)\end{array}$ \\
\hline Household Expenditure (000,000 Rs.) & $\begin{array}{c}-0.735^{* * *} \\
(0.17)\end{array}$ & $\begin{array}{c}-0.613 * * * \\
(0.23)\end{array}$ & $\begin{array}{l}-15.36 \\
(11.45)\end{array}$ & $\begin{array}{l}0.522 \\
(3.23)\end{array}$ & $\begin{array}{c}14.19 \\
(11.40)\end{array}$ & $\begin{array}{c}-2.964 * * \\
(1.45)\end{array}$ \\
\hline Beta (Time inconsistency parameter) & $\begin{array}{c}0.11 \\
(0.12)\end{array}$ & $\begin{array}{l}-0.10 \\
(0.23)\end{array}$ & $\begin{array}{l}-0.129 \\
(5.96)\end{array}$ & $\begin{array}{l}-0.121 \\
(0.79)\end{array}$ & $\begin{array}{c}-0.20 \\
(1.04)\end{array}$ & $\begin{array}{c}0.01 \\
(0.77)\end{array}$ \\
\hline Delta (Discounting parameter) & $\begin{array}{c}-0.0215 \\
(0.19)\end{array}$ & $\begin{array}{c}-0.17 \\
(0.30)\end{array}$ & $\begin{array}{l}2.756 \\
(8.54)\end{array}$ & $\begin{array}{c}-0.00579 \\
(1.15)\end{array}$ & $\begin{array}{l}0.431 \\
(1.74)\end{array}$ & $\begin{array}{l}-0.196 \\
(1.12)\end{array}$ \\
\hline Score on digitspan test & $\begin{array}{c}-0.0301 * * \\
(0.01)\end{array}$ & $\begin{array}{c}0.02 \\
(0.02)\end{array}$ & $\begin{array}{l}0.111 \\
(0.55)\end{array}$ & $\begin{array}{c}0.00996 \\
(0.08)\end{array}$ & $\begin{array}{l}-0.13 \\
(0.12)\end{array}$ & $\begin{array}{l}-0.06 \\
(0.07)\end{array}$ \\
\hline Participates in Seetu & $\begin{array}{c}-0.0352 \\
(0.03)\end{array}$ & $\begin{array}{c}-0.0222 \\
(0.06)\end{array}$ & $\begin{array}{l}-2.479 \\
(1.53)\end{array}$ & $\begin{array}{l}-0.32 \\
(0.21)\end{array}$ & $\begin{array}{c}0.0547 \\
(0.30)\end{array}$ & $\begin{array}{c}-0.522 * * \\
(0.20)\end{array}$ \\
\hline Has a formal account & $\begin{array}{c}0.0871 \text { ** } \\
(0.04)\end{array}$ & $\begin{array}{c}0.03 \\
(0.06)\end{array}$ & $\begin{array}{l}1.266 \\
(1.50)\end{array}$ & $\begin{array}{l}0.135 \\
(0.21)\end{array}$ & $\begin{array}{l}-0.06 \\
(0.30)\end{array}$ & $\begin{array}{c}0.32 \\
(0.20)\end{array}$ \\
\hline Formal Savings Balance $(000,000$ Rs. $)$ & $\begin{array}{c}-0.0658 \\
(0.59)\end{array}$ & $\begin{array}{l}-0.324 \\
(0.91)\end{array}$ & $\begin{array}{c}1.762 \\
(23.14)\end{array}$ & $\begin{array}{l}6.163^{*} \\
(3.15)\end{array}$ & $\begin{array}{c}11.67 * * * \\
(3.91)\end{array}$ & $\begin{array}{l}4.957 \\
(3.20)\end{array}$ \\
\hline Constant & $\begin{array}{c}0.804 * * * \\
(0.29) \\
\end{array}$ & $\begin{array}{c}0.46 \\
(0.44) \\
\end{array}$ & $\begin{array}{c}8.191 \\
(12.06) \\
\end{array}$ & $\begin{array}{c}7.514^{* * * *} \\
(1.64) \\
\end{array}$ & $\begin{array}{c}8.212^{* * *} \\
(2.31) \\
\end{array}$ & $\begin{array}{c}7.440^{* * *} \\
(1.59) \\
\end{array}$ \\
\hline $\begin{array}{l}\text { Observations } \\
\text { R-squared } \\
\text { Mean of Dep Var in sample }\end{array}$ & $\begin{array}{c}389 \\
0.065 \\
0.89\end{array}$ & $\begin{array}{c}389 \\
0.026 \\
0.35\end{array}$ & $\begin{array}{c}389 \\
0.025 \\
13.29\end{array}$ & $\begin{array}{c}347 \\
0.065 \\
7.97\end{array}$ & $\begin{array}{c}136 \\
0.098 \\
8.92\end{array}$ & $\begin{array}{c}344 \\
0.067 \\
7.33\end{array}$ \\
\hline
\end{tabular}

Regression is run at the individual level, using pretreatment averages of covariates (data for rounds 2-5) to explain subsequent uptake and usage of the product in rounds 6-18.

* significant at $10 \%$; ** significant at $5 \%$;** significant at $1 \%$ 
Table 2. Savings Impacts

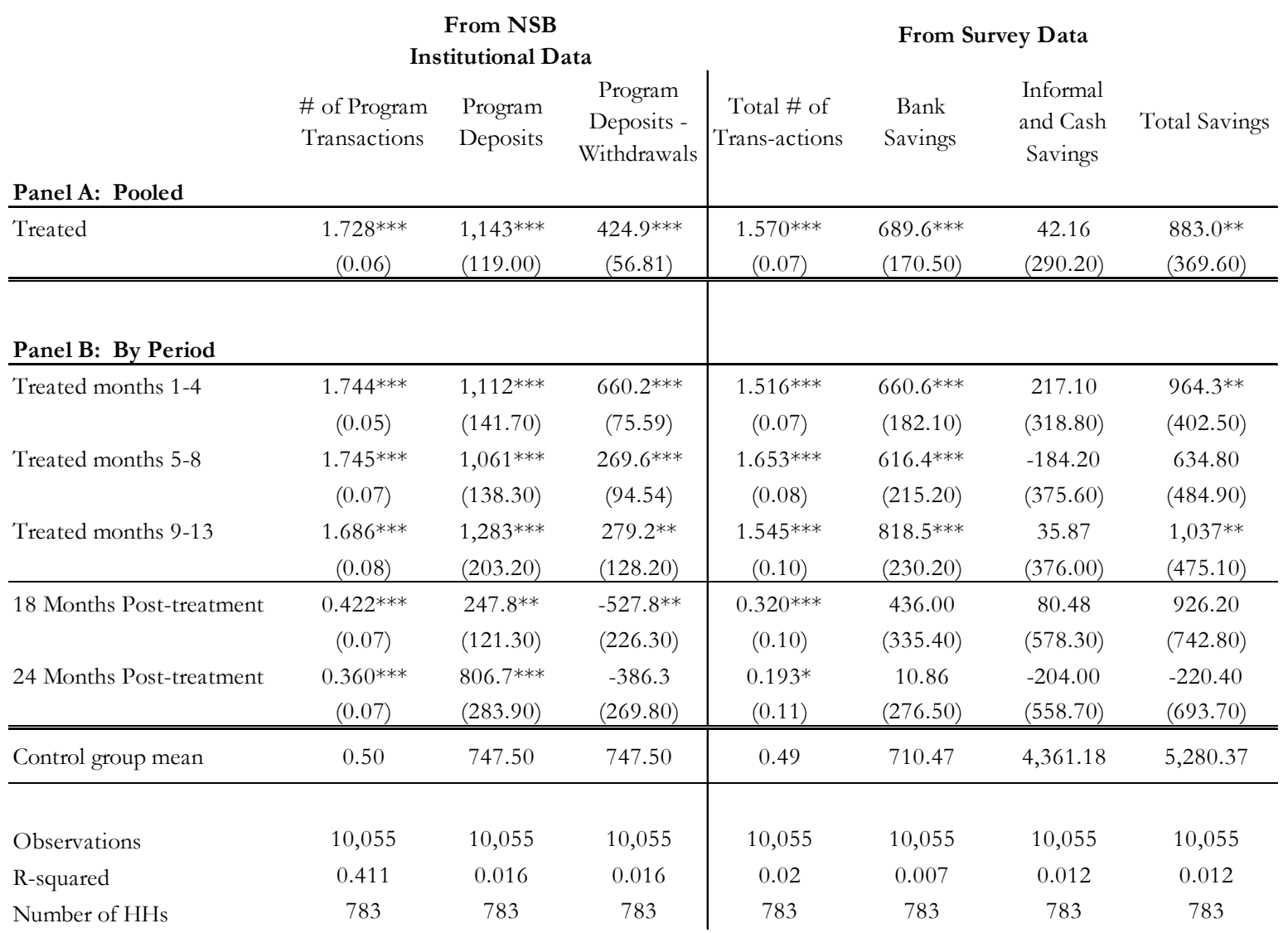

Dependent variables give average monthly flows of savings by type. Individual-level Fixed Effects regression with SEs clustered at

the individual level; regression includes month dummies and uses data for rounds $2-20$. Top $1 \%$ tail of outcome truncated.

* significant at $10 \% ; * *$ significant at $5 \% ; * * *$ significant at $1 \%$

(1) The treatment changed from door-to-door collection to collection from a lock box placed in the cluster of houses in January

2012. The last two surveys were conducted 6 and 12 months after this change. 
Table 3. The Headwaters of Formal Savings

Average Monthly Flows of:

\begin{tabular}{|c|c|c|c|c|c|c|c|}
\hline & $\begin{array}{l}\text { Household } \\
\text { Income }\end{array}$ & $\begin{array}{c}\text { Personal } \\
\text { Income }+ \\
\text { Transfers In }\end{array}$ & $\begin{array}{c}\text { Transfers to } \\
\text { Others }\end{array}$ & $\begin{array}{c}\text { Personal } \\
\text { Consumption }\end{array}$ & $\begin{array}{l}\text { Household } \\
\text { Expenditure }\end{array}$ & $\begin{array}{c}\text { Saved through } \\
\text { ROSCAs }\end{array}$ & $\begin{array}{c}\text { Total Personal } \\
\text { Savings }\end{array}$ \\
\hline \multicolumn{8}{|l|}{ Panel A: Pooled } \\
\hline Treated & $\begin{array}{l}2,980 * * * \\
(1152.00) \\
\end{array}$ & $\begin{array}{c}1,990^{* *} \\
(936) \\
\end{array}$ & $\begin{array}{c}72.61 \\
(236.30) \\
\end{array}$ & $\begin{array}{c}830.9 \\
(657.80) \\
\end{array}$ & $\begin{array}{c}1,586^{*} \\
(868.20) \\
\end{array}$ & $\begin{array}{c}33.11 \\
(76) \\
\end{array}$ & $\begin{array}{c}817.2^{* *} \\
(365) \\
\end{array}$ \\
\hline \multicolumn{8}{|l|}{ Panel B: By Period } \\
\hline Treated months 1-4 & $\begin{array}{c}3,466^{* * *} \\
(1338)\end{array}$ & $\begin{array}{c}2,438^{* *} \\
(1065)\end{array}$ & $\begin{array}{c}86 \\
(276)\end{array}$ & $\begin{array}{l}1,096 \\
(742)\end{array}$ & $\begin{array}{c}2,108^{* *} \\
(1021)\end{array}$ & $\begin{array}{c}55 \\
(72)\end{array}$ & $\begin{array}{c}964.3^{* *} \\
(403)\end{array}$ \\
\hline Treated months 5-8 & $\begin{array}{c}3,271^{* *} \\
(1453)\end{array}$ & $\begin{array}{c}1,816 \\
(1216)\end{array}$ & $\begin{array}{c}127 \\
(311)\end{array}$ & $\begin{array}{c}826 \\
(863)\end{array}$ & $\begin{array}{c}1,183 \\
(1075)\end{array}$ & $\begin{array}{c}6 \\
(95)\end{array}$ & $\begin{array}{c}635 \\
(485)\end{array}$ \\
\hline Treated months 9-13 & $\begin{array}{l}2,495 \\
(1616) \\
\end{array}$ & $\begin{array}{l}1,878 \\
(1276) \\
\end{array}$ & $\begin{array}{c}114 \\
(368)\end{array}$ & $\begin{array}{r}515 \\
(853) \\
\end{array}$ & $\begin{array}{l}1,291 \\
(1159) \\
\end{array}$ & $\begin{array}{c}-9 \\
(115) \\
\end{array}$ & $\begin{array}{c}1,037 * * \\
(475)\end{array}$ \\
\hline 18 Months Post-treatment (1) & $\begin{array}{l}3,038 \\
(2134)\end{array}$ & $\begin{array}{l}2,369 \\
(1850)\end{array}$ & $\begin{array}{l}-258 \\
(643)\end{array}$ & $\begin{array}{l}1,235 \\
(1182)\end{array}$ & $\begin{array}{l}2,402 \\
(1489)\end{array}$ & $\begin{array}{c}171 \\
(154)\end{array}$ & $\begin{array}{c}926 \\
(743)\end{array}$ \\
\hline 24 Months Post-treatment (1) & $\begin{array}{c}83 \\
(2156) \\
\end{array}$ & $\begin{array}{r}85 \\
(1855) \\
\end{array}$ & $\begin{array}{l}-198 \\
(666) \\
\end{array}$ & $\begin{array}{c}90 \\
(1126) \\
\end{array}$ & $\begin{array}{c}937 \\
(1415) \\
\end{array}$ & $\begin{array}{r}100 \\
(151) \\
\end{array}$ & $\begin{array}{l}-220 \\
(694) \\
\end{array}$ \\
\hline Control group mean & 29,393 & 20,251 & $3,215.88$ & 11,040 & 18,159 & 1,442 & 5,213 \\
\hline Observations & 10,055 & 10,055 & 10,055 & 10,055 & 10,055 & 10,055 & 10,055 \\
\hline R-squared & 0.032 & 0.024 & 0.016 & 0.024 & 0.03 & 0.02 & 0.012 \\
\hline Number of HHs & 783 & 783 & 783 & 783 & 783 & 783 & 783 \\
\hline
\end{tabular}

Individual-level Fixed Effects regression with SEs clustered at the individual level; regression includes month dummies and uses data

for rounds $2-20$. Top $1 \%$ tail of outcome truncated.

* significant at $10 \%$; ** significant at $5 \%$; *** significant at $1 \%$

(1) The treatment changed from door-to-door collection to collection from a lock box placed in the cluster of houses in January 2012 . The last two surveys were conducted 6 and 12 months after this change. 
Table 4.1. Income Impacts on those Not Always Self-Employed at Baseline

All

(1)

(2)

Total Hours Total Personal worked

Income
(3)

Self

Ever Not Self-Employed during Baseline Rounds 1-5
(4)
(5)
(6)

(7)

$\begin{array}{cccc}\text { Hours Worked } & \text { Wage Hours } & \text { Monthly } & \text { Total Personal } \\ \text { in SE } & \text { Worked } & \text { Wages } & \text { Income }\end{array}$

Panel A: Pooled

\begin{tabular}{lcccccc} 
Panel A: Pooled & 1.322 & $2,108^{* *}$ & $-0.0335^{* *}$ & -1.056 & $1.723^{* *}$ & 333.5 \\
Treated & $(0.92)$ & $(951)$ & $(0.01)$ & $(0.86)$ & $(0.80)$ & $(209)$ \\
\hline \hline
\end{tabular}

\begin{tabular}{|c|c|c|c|c|c|c|c|}
\hline \multirow[t]{2}{*}{ Treated months 1-4 } & 1.007 & $2,438^{* *}$ & $-0.0343^{* * *}$ & -1.023 & $1.426^{* *}$ & -35.25 & 1,102 \\
\hline & $(0.93)$ & $(1065)$ & $(0.012)$ & $(0.63)$ & $(0.69)$ & $(205)$ & $(1477)$ \\
\hline \multirow[t]{2}{*}{ Treated months 5-8 } & 1.340 & 1,816 & $-0.0283^{*}$ & -1.069 & 1.356 & $501.9 * *$ & 1,876 \\
\hline & $(1.06)$ & $(1216)$ & $(0.017)$ & $(1.03)$ & $(0.95)$ & (249) & $(1696)$ \\
\hline \multirow[t]{2}{*}{ Treated months 9-13 } & 1.727 & 1,878 & $-0.0398^{*}$ & -1.182 & $2.612 * *$ & $633.7 *$ & 1,137 \\
\hline & $(1.40)$ & $(1276)$ & $(0.022)$ & $(1.48)$ & $(1.25)$ & $(356)$ & $(1777)$ \\
\hline \multirow[t]{2}{*}{ Post-treatment month 18} & -2.099 & 2,369 & -0.0448 & -0.786 & 1.415 & $1,046^{* *}$ & 3,018 \\
\hline & $(1.73)$ & $(1850)$ & $(0.029)$ & $(1.85)$ & $(1.61)$ & $(478)$ & $(2687)$ \\
\hline \multirow[t]{2}{*}{ Post-treatment month 24} & 2.124 & 85 & -0.0277 & 1.284 & $3.111 *$ & 906 & 519 \\
\hline & $(2.01)$ & $(1855)$ & $(0.030)$ & $(1.77)$ & $(1.80)$ & $(607)$ & $(2830)$ \\
\hline Observations & 10,055 & 10,055 & 10,055 & 5,222 & 5,222 & 5,222 & 5,222 \\
\hline R-squared & 0.006 & 0.024 & 0.005 & 0.028 & 0.012 & 0.033 & 0.02 \\
\hline Number of HHs & 783 & 783 & 783 & 401 & 401 & 401 & 401 \\
\hline Control Group Mean & 30.99 & 20,251 & 0.533 & 4.50 & 9.62 & 2,092 & 19,674 \\
\hline
\end{tabular}

Individual-level Fixed Effects regression with SEs clustered at the individual level; regression includes month dummies and uses data for rounds 2-20. Top 1\% tail of outcome truncated. Missing business outcomes for the ever self-employed sample (indicating that respondents were not self-employed in that survey round) are replaced with zeros.

* significant at $10 \%$; ** significant at $5 \%$; *** significant at $1 \%$ 
Table 4.2. Income Impacts on those Always Self-Employed at Baseline

Always Self-Employed during Baseline Rounds 1-5
(1)
(2)
(3)
(4)
(5)
(6)
(7)
(8)

\begin{tabular}{|c|c|c|c|c|c|c|c|}
\hline $\begin{array}{l}\text { Hours Worked } \\
\quad \text { in SE }\end{array}$ & $\begin{array}{l}\text { Wage Hours } \\
\text { Worked }\end{array}$ & $\begin{array}{c}\text { Wages Paid to } \\
\text { Employees }\end{array}$ & $\begin{array}{c}\text { Monthly } \\
\text { Business Sales }\end{array}$ & $\begin{array}{l}\text { Total Value of } \\
\text { Inventory in } \\
\text { Business }\end{array}$ & $\begin{array}{l}\text { Total Value of } \\
\text { Fixed Assets in } \\
\text { Business }\end{array}$ & $\begin{array}{l}\text { Monthly SE } \\
\text { Income }\end{array}$ & $\begin{array}{l}\text { Total } \\
\text { Personal } \\
\text { Income }\end{array}$ \\
\hline
\end{tabular}

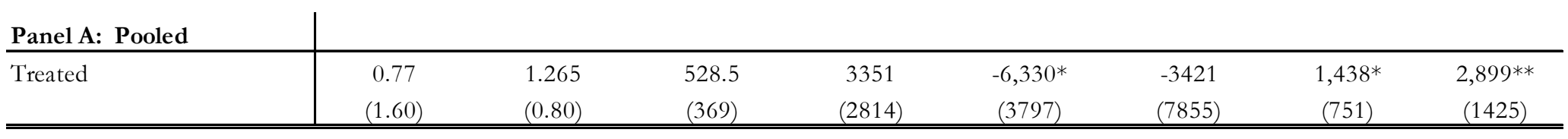

\begin{tabular}{|c|c|c|c|c|c|c|c|c|}
\hline Treated months $1-4$ & $\begin{array}{l}1.018 \\
(1.68)\end{array}$ & $\begin{array}{l}0.776 \\
(0.55)\end{array}$ & $\begin{array}{c}606 \\
(422)\end{array}$ & $\begin{array}{c}7,003 * * \\
(3420)\end{array}$ & $\begin{array}{l}-1,091 \\
(3437)\end{array}$ & $\begin{array}{c}-1766 \\
(5,298)\end{array}$ & $\begin{array}{c}1,881 * * \\
(806)\end{array}$ & $\begin{array}{c}3,933 * * \\
(1535)\end{array}$ \\
\hline Treated months 5-8 & $\begin{array}{l}1.154 \\
(1.83)\end{array}$ & $\begin{array}{l}1.473 \\
(1.00)\end{array}$ & $\begin{array}{c}519 \\
(427)\end{array}$ & $\begin{array}{c}3,323 \\
(3010)\end{array}$ & $\begin{array}{l}-5,726 \\
(4530)\end{array}$ & $\begin{array}{l}-6,136 \\
(7,848)\end{array}$ & $\begin{array}{c}1,429 * \\
(845)\end{array}$ & $\begin{array}{c}1,828 \\
(1753)\end{array}$ \\
\hline Treated months 9-13 & $\begin{array}{r}-0.056 \\
(2.43) \\
\end{array}$ & $\begin{array}{l}1.742 \\
(1.26) \\
\end{array}$ & $\begin{array}{r}465 \\
(419) \\
\end{array}$ & $\begin{array}{l}-2,121 \\
(4181) \\
\end{array}$ & $\begin{array}{c}-15,275^{* *} \\
(6392) \\
\end{array}$ & $\begin{array}{c}-2,037 \\
(15,247) \\
\end{array}$ & $\begin{array}{c}799 \\
(1094) \\
\end{array}$ & $\begin{array}{l}2,806 \\
(1840) \\
\end{array}$ \\
\hline Post-treatment month 18 & $\begin{array}{c}-7.775^{* * *} \\
(2.95)\end{array}$ & $\begin{array}{l}2.036 \\
(1.70)\end{array}$ & $\begin{array}{c}158 \\
(714)\end{array}$ & $\begin{array}{c}-9,714^{*} \\
(5744)\end{array}$ & $\begin{array}{l}-9,748 \\
(7110)\end{array}$ & $\begin{array}{c}-3,528 \\
(16,640)\end{array}$ & $\begin{array}{c}-449 \\
(1270)\end{array}$ & $\begin{array}{l}1,724 \\
(2520)\end{array}$ \\
\hline Post-treatment month 24 & $\begin{array}{c}-4.012 \\
(3.26) \\
\end{array}$ & $\begin{array}{l}2.736 \\
(1.85) \\
\end{array}$ & $\begin{array}{l}-590 \\
(528) \\
\end{array}$ & $\begin{array}{c}-12,082 * \\
(6283) \\
\end{array}$ & $\begin{array}{l}-4,182 \\
(9465) \\
\end{array}$ & $\begin{array}{c}1,709 \\
(18,113) \\
\end{array}$ & $\begin{array}{c}-3,470 * * \\
(1590) \\
\end{array}$ & $\begin{array}{c}-336 \\
(2304) \\
\end{array}$ \\
\hline Observations & 4,833 & 4,833 & 4,833 & 4,833 & 4,833 & 4,833 & 4,833 & 4,833 \\
\hline R-squared & 0.023 & 0.03 & 0.009 & 0.035 & 0.02 & 0.155 & 0.06 & 0.035 \\
\hline Number of HHs & 382 & 382 & 382 & 382 & 382 & 382 & 382 & 382 \\
\hline Control Group Mean & 47.30 & 2.00 & 1,480 & 34,401 & 38,136 & 106,019 & 11,015 & 20,887 \\
\hline
\end{tabular}

Individual-level Fixed Effects regression with SEs clustered at the individual level; regression includes month dummies and uses data for rounds 2-20. Top $1 \%$ tail of outcome truncated. Missing business outcomes for the ever self-employed sample (indicating that respondents were not self-employed in that survey round) are replaced with zeros.

* significant at $10 \%$; ** significant at $5 \%$; *** significant at $1 \%$ 
Table 5. Consumption Impacts

\begin{tabular}{|c|c|c|c|c|c|c|c|c|c|c|}
\hline Baseline Characteristics: & $\begin{array}{c}\text { Monthly } \\
\text { Household } \\
\text { Consumption }\end{array}$ & $\begin{array}{c}\text { Monthly } \\
\text { Household } \\
\text { Consumption } \\
\text { of Durables }\end{array}$ & $\begin{array}{c}\text { Monthly } \\
\text { Individual } \\
\text { Consumption }\end{array}$ & $\begin{array}{c}\text { Reported } \\
\text { 'Sin Good' } \\
\text { Consumption }\end{array}$ & $\begin{array}{c}\text { Survey } \\
\text { Experiment } \\
\text { Fraction } \\
\text { 'Sin Goods' } \\
\text { Consumed }\end{array}$ & $\begin{array}{c}\text { Monthly } \\
\text { Financial } \\
\text { Transactions }\end{array}$ & $\begin{array}{c}\text { Non-Program } \\
\text { Financial } \\
\text { Transactions }\end{array}$ & $\begin{array}{c}\text { Monthly } \\
\text { Bank Savings }\end{array}$ & $\begin{array}{l}\text { Monthly Non- } \\
\text { Bank Savings }\end{array}$ & $\begin{array}{l}\text { Total Monthly } \\
\text { Savings }\end{array}$ \\
\hline $\begin{array}{l}\text { Time Inconsistency } * \text { Treatment } \\
\text { (inverse of 'beta' parameter) }\end{array}$ & $\begin{array}{c}-480 \\
(3693)\end{array}$ & $\begin{array}{l}-1212 \\
(1387)\end{array}$ & $\begin{array}{l}-1117 \\
(2356)\end{array}$ & $\begin{array}{l}-56 \\
(114)\end{array}$ & $\begin{array}{c}0.0185 \\
(0.14)\end{array}$ & $\begin{array}{c}0.546^{*} \\
(0.31)\end{array}$ & $\begin{array}{c}0.595^{* * *} \\
(0.22)\end{array}$ & $\begin{array}{c}801.1 \\
(604.90)\end{array}$ & $\begin{array}{c}1,574^{*} \\
(831)\end{array}$ & $\begin{array}{l}2,318^{*} \\
(1239)\end{array}$ \\
\hline Treatment Effect at Mean: & $\begin{array}{c}1,577^{*} \\
(876.80)\end{array}$ & $\begin{array}{c}-216.3 \\
(449.60)\end{array}$ & $\begin{array}{c}809.3 \\
(661.90)\end{array}$ & $\begin{array}{c}0.774 \\
(30.12)\end{array}$ & $\begin{array}{c}-0.00653 \\
(0.03)\end{array}$ & $\begin{array}{c}1.464^{* * *} \\
(0.09)\end{array}$ & $\begin{array}{c}-0.140^{*} \\
(0.08)\end{array}$ & $\begin{array}{l}654.7 * * * \\
(165.20)\end{array}$ & $\begin{array}{c}52.71 \\
(289.00)\end{array}$ & $\begin{array}{l}862.0^{* *} \\
(365.80)\end{array}$ \\
\hline Constant & $\begin{array}{c}18,548^{* * *} \\
(612.80) \\
\end{array}$ & $\begin{array}{l}2,738 * * * \\
(302.20) \\
\end{array}$ & $\begin{array}{c}10,628^{* * *} \\
(431.60) \\
\end{array}$ & $\begin{array}{c}463.8^{* * * *} \\
(22.37) \\
\end{array}$ & $\begin{array}{c}0.132^{* * *} \\
(0.02) \\
\end{array}$ & $\begin{array}{c}0.715^{* * *} \\
(0.08) \\
\end{array}$ & $\begin{array}{c}0.715^{* * *} \\
(0.08) \\
\end{array}$ & $\begin{array}{c}568.2^{* * *} \\
(91.36) \\
\end{array}$ & $\begin{array}{l}4,085^{* * *} \\
(213.20) \\
\end{array}$ & $\begin{array}{l}4,784 * * * \\
(257.40) \\
\end{array}$ \\
\hline Observations & 10,055 & 10,055 & 10,055 & 10,055 & 1,986 & 10,055 & 10,055 & 10,055 & 10,055 & 10,055 \\
\hline R-squared & 0.03 & 0.034 & 0.023 & 0.037 & 0.016 & 0.11 & 0.014 & 0.009 & 0.012 & 0.012 \\
\hline Number of Individuals & 783 & 783 & 783 & 783 & 775 & 783 & 783 & 783 & 783 & 783 \\
\hline Control Group Mean & 18,159 & 2,490 & 11,040 & 513 & 0.1548 & 0.533 & 0.527 & 757 & 4,307 & 5,213 \\
\hline
\end{tabular}

Regressions include individual-level fixed effects and SEs are clustered at the individual level, regression includes month dummies and uses data for rounds $2-20$. Top $1 \%$ tail of outcome truncated.

* significant at $10 \%$; ** significant at $5 \%$; *** significant at $1 \%$ 
Table 6. The Randomized Saturation Experiment within ROSCAs.

\begin{tabular}{|c|c|c|c|c|c|c|c|c|c|c|}
\hline \multirow[b]{2}{*}{ Treated } & \multicolumn{2}{|c|}{$\begin{array}{c}\text { Number of Seetus } \\
\text { currently Participating in }\end{array}$} & \multicolumn{2}{|c|}{$\begin{array}{c}\text { Monthly amount Saved } \\
\text { through Seetus }\end{array}$} & \multicolumn{2}{|c|}{$\begin{array}{c}\text { Monthly Transfers FROM } \\
\text { Outside the Household }\end{array}$} & \multicolumn{2}{|c|}{$\begin{array}{l}\text { Monthly Transfers TO } \\
\text { Outside the Household }\end{array}$} & \multicolumn{2}{|c|}{ Total Monthly Savings } \\
\hline & $\begin{array}{c}0.293^{* * *} \\
(0.11)\end{array}$ & $\begin{array}{c}0.182^{*} \\
(0.10)\end{array}$ & $\begin{array}{l}286.9^{*} \\
(156.2)\end{array}$ & $\begin{array}{l}254.7 * \\
(154.2)\end{array}$ & $\begin{array}{c}946.7 \\
(997.8)\end{array}$ & $\begin{array}{c}888.6 \\
(1055.0)\end{array}$ & $\begin{array}{l}-25.34 \\
(83.6)\end{array}$ & $\begin{array}{l}-32.5 \\
(89.7)\end{array}$ & $\begin{array}{c}939.5 \\
(631.2)\end{array}$ & $\begin{array}{c}836.9 \\
(656.3)\end{array}$ \\
\hline Seetu Treatment Saturation & & $\begin{array}{c}1.435^{* * *} \\
(0.49)\end{array}$ & & $\begin{array}{c}415 \\
(537.3)\end{array}$ & & $\begin{array}{c}750 \\
(3444.0)\end{array}$ & & $\begin{array}{c}92 \\
(288.5)\end{array}$ & & $\begin{array}{c}1324 \\
(1987.0)\end{array}$ \\
\hline Constant & $\begin{array}{c}2.034 * * * \\
(0.06) \\
\end{array}$ & $\begin{array}{c}2.032^{* * * *} \\
(0.06) \\
\end{array}$ & $\begin{array}{c}2,215^{* * *} \\
(86.15) \\
\end{array}$ & $\begin{array}{c}2,214^{* * *} \\
(86.10) \\
\end{array}$ & $\begin{array}{l}4,460 * * * \\
(703.70) \\
\end{array}$ & $\begin{array}{l}4,459 * * * \\
(703.30) \\
\end{array}$ & $\begin{array}{c}479.7 * * * \\
(59.58) \\
\end{array}$ & $\begin{array}{c}479.6^{* * *} \\
(59.53) \\
\end{array}$ & $\begin{array}{l}5,547 * * * \\
(379.00) \\
\end{array}$ & $\begin{array}{l}5,545^{* * *} \\
(378.10) \\
\end{array}$ \\
\hline Observations & 3,255 & 3,255 & 3,255 & 3,255 & 3,255 & 3,255 & 3,255 & 3,255 & 3,255 & 3,255 \\
\hline R-squared & 0.032 & 0.043 & 0.03 & 0.03 & 0.012 & 0.012 & 0.067 & 0.067 & 0.026 & 0.026 \\
\hline Number of $\mathrm{HHs}$ & 278 & 278 & 278 & 278 & 278 & 278 & 278 & 278 & 278 & 278 \\
\hline
\end{tabular}

Regression with fixed effects at the individual and survey wave level with standard errors clustered at the individual level. Table includes data from round $1-18$ on households that were members of ROSCAs within with the saturation experiment was conducted (no more than 24 ROSCA members all of whom lived in the same zone); treatment of nonstudy ROSCA members began in round 6.

* significant at $10 \%$; ** significant at $5 \%$; *** significant at $1 \%$ 
FIGURES:

Figure 1.

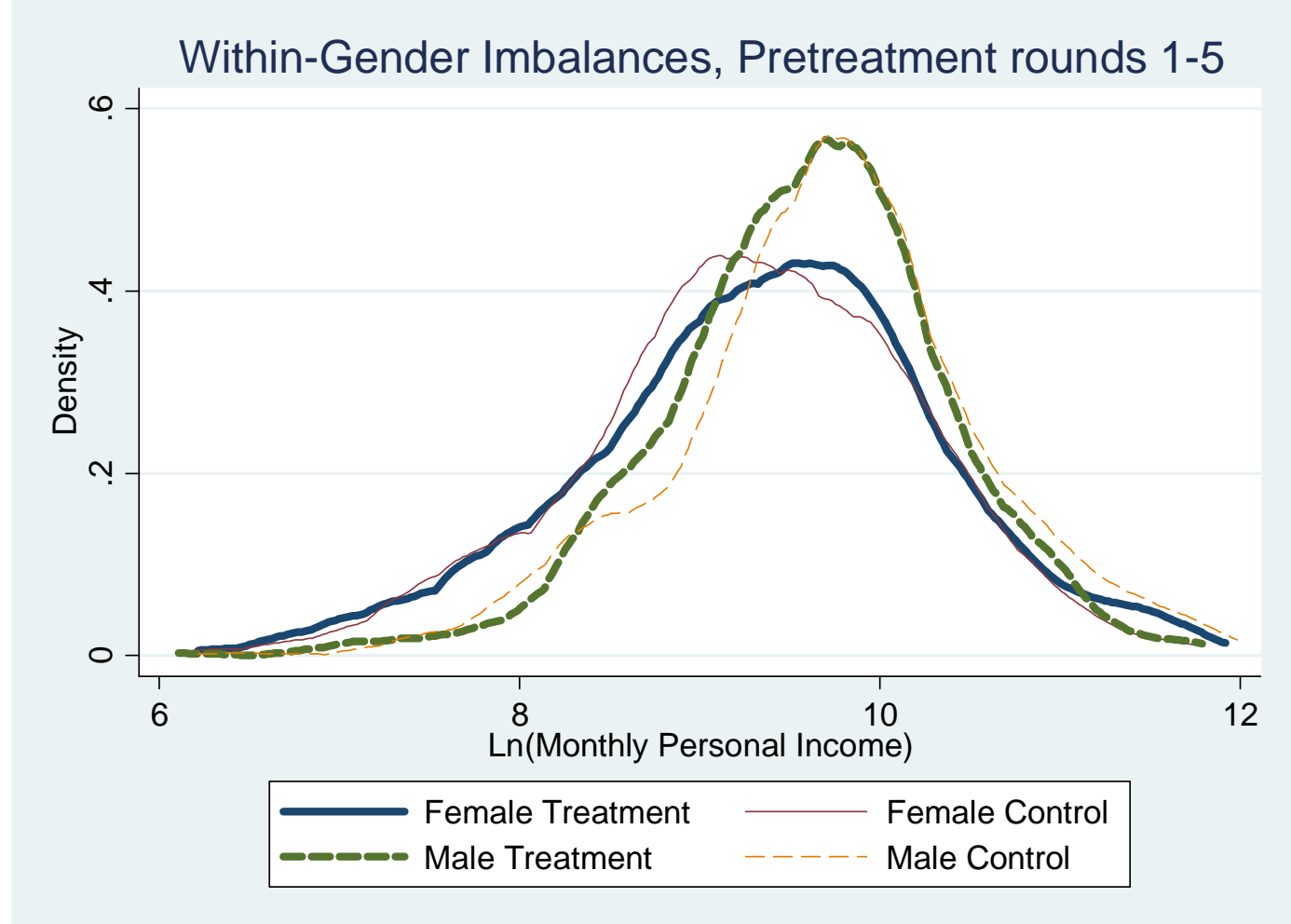


Figure 2.

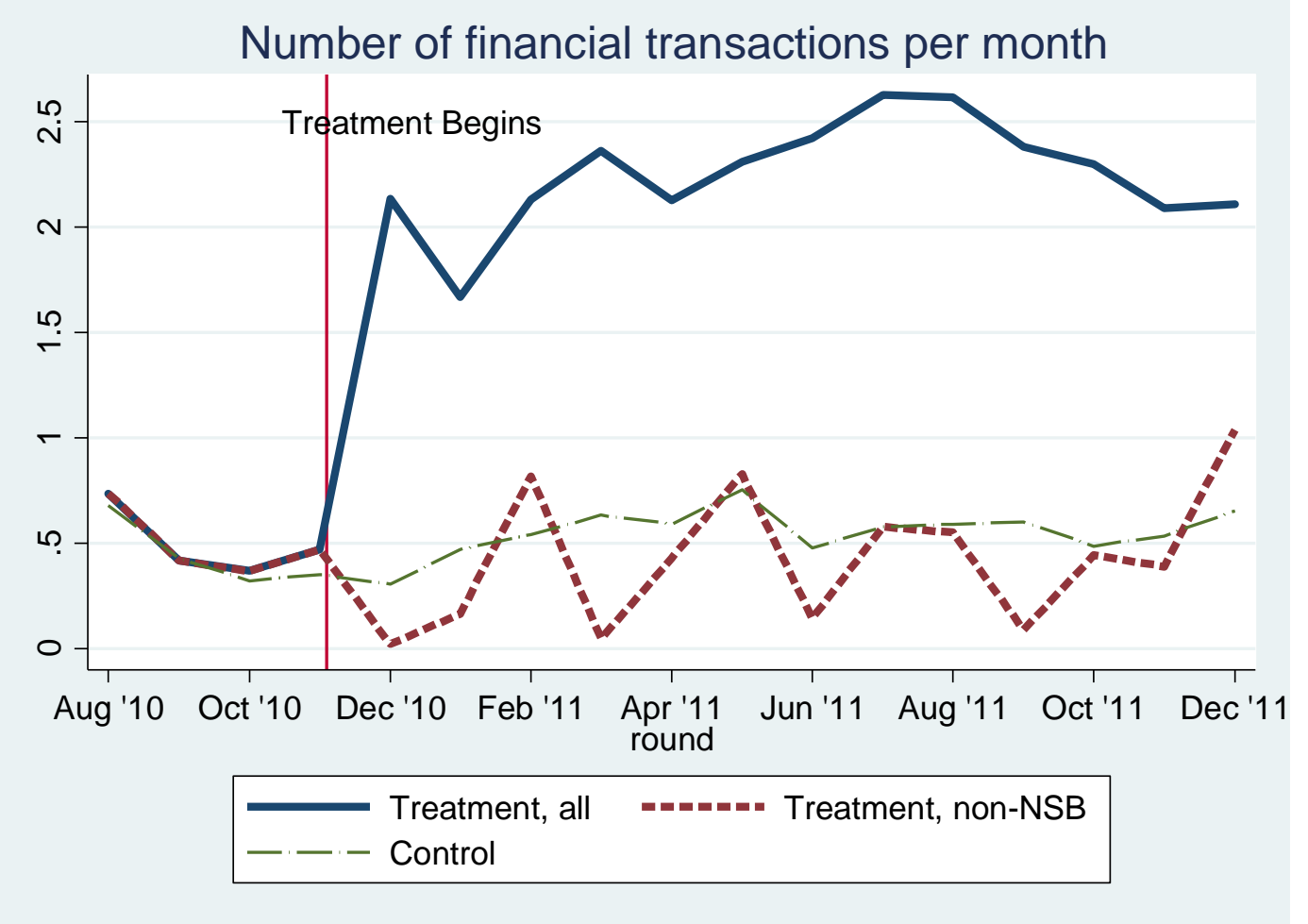


Figure 3.

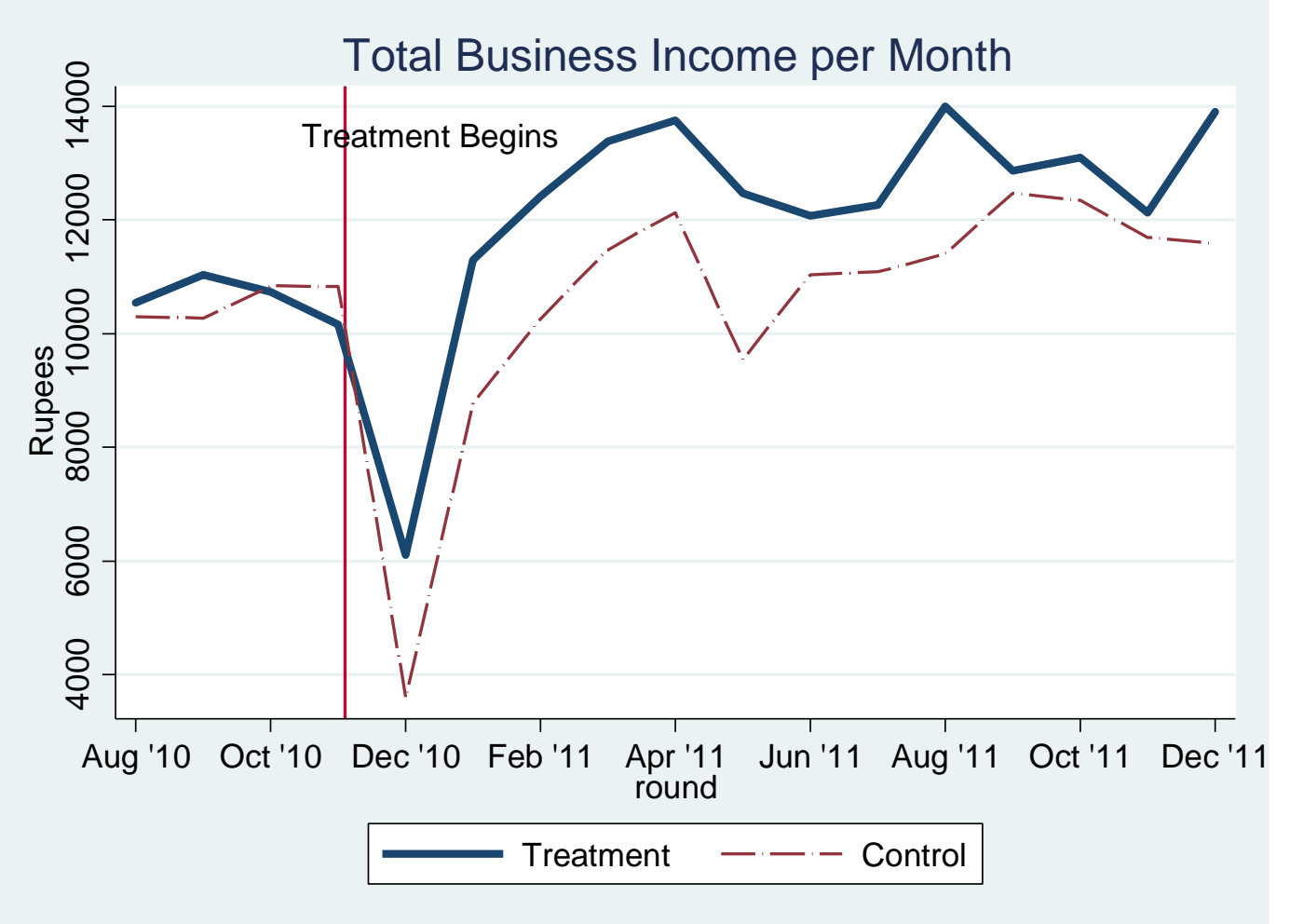


Table A1. Survey Design.

\section{Treatment}

Round Month

1

2

3

4

5

6

7

\begin{tabular}{|c|c|c|c|c|c|}
\hline $\begin{array}{c}\text { Pure } \\
\text { Control }\end{array}$ & $\begin{array}{l}\text { Control to } \\
\text { Weekly } \\
\text { Box }\end{array}$ & $\begin{array}{c}\text { Control to } \\
\text { Biweekly } \\
\text { Box }\end{array}$ & $\begin{array}{c}\text { Weekly } \\
\text { Home } \\
\text { visits }\end{array}$ & $\begin{array}{c}\text { Weekly to } \\
\text { Biweekly } \\
\text { Home } \\
\text { visits }\end{array}$ & $\begin{array}{l}\text { Weekly } \\
\text { Home to } \\
\text { Weekly } \\
\text { Box }\end{array}$ \\
\hline $\begin{array}{l}52 \text { zones, } \\
256 \text { hhs }\end{array}$ & $\begin{array}{c}13 \text { zones, } \\
89 \text { hhs }\end{array}$ & $\begin{array}{c}13 \text { zones, } \\
61 \mathrm{hhs}\end{array}$ & $\begin{array}{c}40 \text { zones, } \\
197 \text { hhs }\end{array}$ & $\begin{array}{c}19 \text { zones, } \\
85 \text { hhs }\end{array}$ & $\begin{array}{c}19 \text { zones, } \\
107 \text { hhs }\end{array}$ \\
\hline & & & & & \\
\hline & & & & & \\
\hline & & & & & \\
\hline & & & & & \\
\hline & & & & & \\
\hline & & & & & \\
\hline & & & & & \\
\hline & & & & & \\
\hline & & & & & \\
\hline & & & & & \\
\hline & & & & & \\
\hline & & & & & \\
\hline & & & & & \\
\hline & & & & & \\
\hline & & & & & \\
\hline & & & & & \\
\hline & & & & & \\
\hline & & & & & \\
\hline & & & & & \\
\hline & & & & & \\
\hline & & & & & \\
\hline
\end{tabular}

Yellow boxes indicate survey waves used in the study of Weekly Home Visits

Blue boxes indicate Treatment with Weekly Home visits, as well as inclusion in the study of Weekly Home Visits

Green boxes indicates samples for which surveys are not included in the sample because of a substantial change in the treatment protocol 
Table A2. Determinants of Attrition.

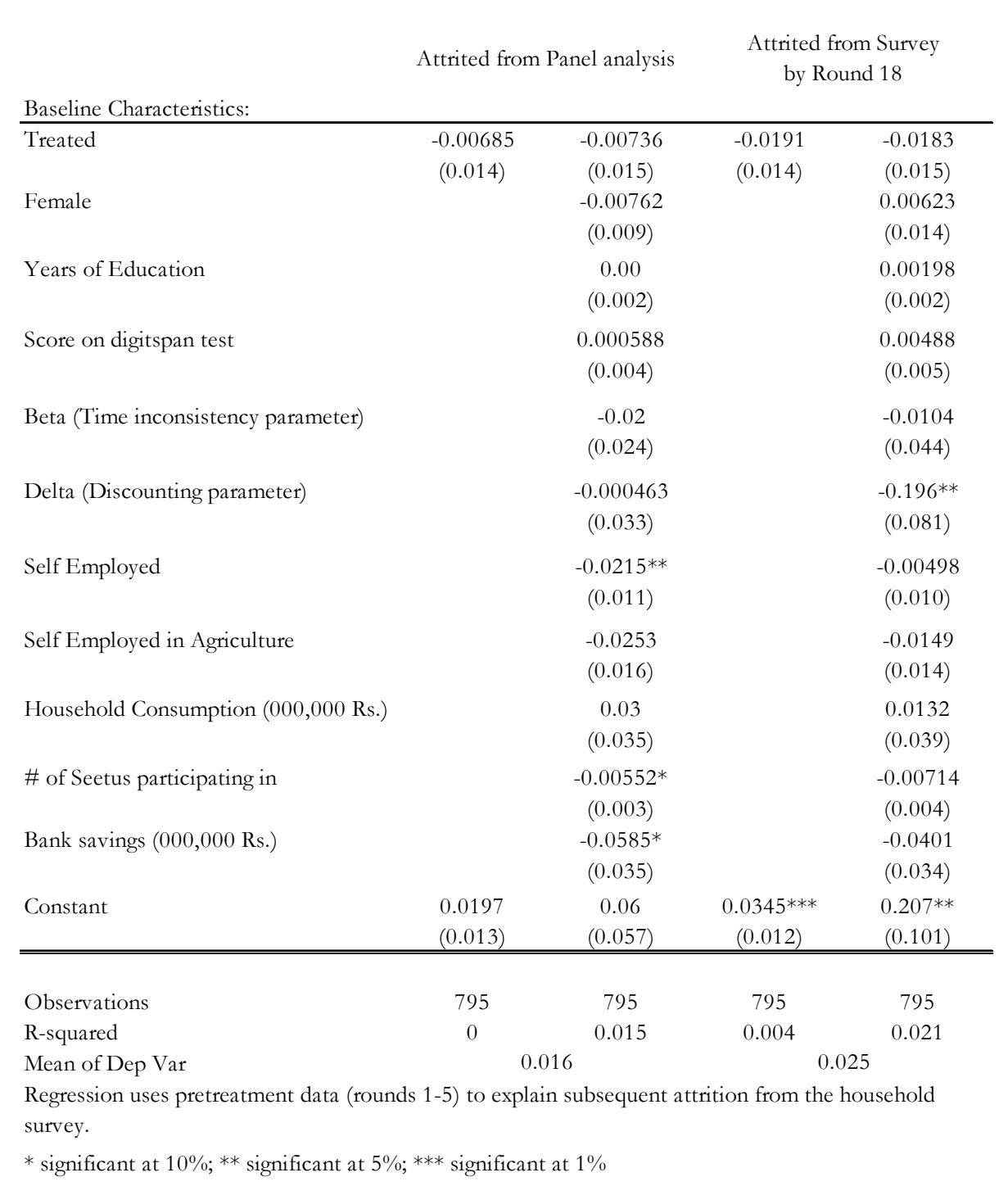




\section{Table A3. Balance.}

Variable:

Number of transactions with a formal financial institution during previous month

Female

Discount Factor (delta)

Time Consistency Factor (beta)

Total number of seetus in which respondent participated in previous month

Total payouts from seetus in previous month

Respondent reports being self-employed in non-ag enterprise during previous month

Total asset purchases over previous month

Total value of business inventory

Total business expenses over previous month

Total business sales over previous month

Total business income over previous month

Number of transactions with a financial institution other than NSB over previous month

Total amount saved through ROSCAs over previous month

Total amount withdrawn from ROSCAs over previous month

Total amount put into informal savings over previous month

Total amount withdrawn from informal savings over previous month

Total change in household cash balance over previous month

Total amount received in loans over previous month

Aggregate income over previous month

Aggregate consumption over previous month

Earned household income over previous mont

Total household income over previous month

Personal income taken from informal savings over previous month

Transfer from spouse over previous month

Transfer from outside the household over previous mont

Total personal income over previous month

Transfers to spouse over previous month

Transfers to children over previous month

Transfers to anyone over previous month

Monthly savings into banks

Month savings in cash

Monthly savings through ROSCAs

Monthly savings through other means

Total Monthly savings over previous month month are included, and standard errors are clustered at the zone level to reflect the design effect.

* significant at $10 \%$; ** significant at $5 \%$; *** significant at $1 \%$
Treatment-

Mean in control SE of

control differential difference

$\begin{array}{lll}0.52 & 0.0116 & (0.08) \\ 0.92 & 0.00955 & (0.01)\end{array}$

$0.92 \quad 0.00955 \quad(0.01)$

$\begin{array}{lll}0.97 & 0.0181 \quad(0.01)\end{array}$

$\begin{array}{lll}1.23 & -0.0704 & (0.11) \\ 948 & -125.7 & (177)\end{array}$

$\begin{array}{lll}0.51 & 0.0205 & (0.04)\end{array}$

$529 \quad-57.71 \quad(144)$

$\begin{array}{lll}35,491 & 6,204 & (8113) \\ 20,327 & 2490 & (3281)\end{array}$

$31,561-2013-(4116)$

$\begin{array}{lll}10,497 & 234.2 \quad(1098)\end{array}$

$\begin{array}{lll}0.41 & -0.0175 & (0.04)\end{array}$

$\begin{array}{lll}0,470 & -116.9 & (185)\end{array}$

$-303.2$

$2,001 \quad-200.4 \quad(287)$

$585 \quad-712.9 * \quad(397)$

$-116.6 \quad(407)$

$\begin{array}{lll}2,853 & -686.9 & (975)\end{array}$

$\begin{array}{lll}8,672 & -769.50 \quad(954)\end{array}$

$\begin{array}{lll}22,195 & -1,049 & (1014)\end{array}$

$-1656-(1427)$

$\begin{array}{ll}-1,437 & \text { (997) }\end{array}$

$\begin{array}{lcl}3,637 & -150.8 & (403)\end{array}$

$21,157 \quad-1,277 \quad$ (1180)

$1,945 \quad 172$

$257.34 \quad-6.778 \quad(36)$

$\begin{array}{lll}3,077 & -15.01 \quad(266)\end{array}$

$762 \quad-135.8 \quad(133)$

$\begin{array}{lll}2,426 & -249 & (239)\end{array}$

$\begin{array}{lll}1,481 & -88.97 \quad(193)\end{array}$

$\begin{array}{lll}1,481 & -88.97 & (193) \\ 416.96 & -29.71 & (60)\end{array}$ 
Table A4. Detailed Analysis of Headwaters.

\begin{tabular}{|c|c|c|c|c|c|c|c|}
\hline \multirow[b]{3}{*}{ Category: } & \multirow[b]{3}{*}{ Variable: } & \multicolumn{2}{|c|}{$\begin{array}{c}\text { Regression } \\
\text { Coefficients }\end{array}$} & \multicolumn{4}{|c|}{$\begin{array}{c}\text { Liquidity Balance } \\
\text { (positive number indicates incoming } \\
\text { liquidity for core respondent) }\end{array}$} \\
\hline & & \multicolumn{3}{|c|}{ Full year of study: } & \multicolumn{3}{|c|}{ By Period: } \\
\hline & & Coeff & SE & Full Year & $\begin{array}{c}\text { Months } \\
1-4\end{array}$ & $\begin{array}{c}\text { Months } \\
\text { 5-8 }\end{array}$ & $\begin{array}{c}\text { Months } \\
9-13\end{array}$ \\
\hline \multirow[t]{7}{*}{ Informal Savings: } & Saved through ROSCAs & 81.05 & $(86.95)$ & & & & \\
\hline & Saved in gold & -81.67 & $(79.67)$ & & & & \\
\hline & Saved in durables & 249.2 & (262.30) & & & & \\
\hline & Saved in land & $303.0^{*}$ & $(178.40)$ & & & & \\
\hline & Informal loans repaid & -53.73 & $(213.00)$ & & & & \\
\hline & Saved through other means & 155.8 & (106.90) & & & & \\
\hline & Total informal savings & 651.6 & $(430.30)$ & -651.6 & -526.7 & -942.5 & -466.9 \\
\hline \multirow[t]{7}{*}{ Informal Withdrawals: } & Withdrawn from ROSCAs & -241.5 & $(405.50)$ & & & & \\
\hline & Withdrawn from gold & 96.49 & $(232.00)$ & & & & \\
\hline & Withdrawn from durables & 8.474 & $(32.47)$ & & & & \\
\hline & Withdrawn from land & 26.64 & (47.18) & & & & \\
\hline & Withdrawn informal loans & 84.51 & $(83.43)$ & & & & \\
\hline & Withdrawn from other & -23.12 & $(34.29)$ & & & & \\
\hline & Total informal withdrawals & -48.55 & $(454.80)$ & -48.55 & 520.5 & -161.7 & -350.5 \\
\hline \multirow[t]{4}{*}{ Loans Received: } & Government loans received & 36.29 & $(212.70)$ & & & & \\
\hline & MFI loans received & -26.17 & $(27.82)$ & & & & \\
\hline & Bank loans received & 25.74 & $(82.32)$ & & & & \\
\hline & Total loans received & -8.367 & $(425.10)$ & -8.367 & -173.9 & 190.5 & -22.8 \\
\hline Loans Paid Back: & Total loan repayment & 73.42 & (198.10) & -73.42 & -237 & -59.73 & 137.9 \\
\hline \multirow[t]{5}{*}{ Individual Consumption: } & Spending on tobacco & -18.37 & $(13.57)$ & & & & \\
\hline & Spending on alcohol & -6.537 & $(11.87)$ & & & & \\
\hline & Spending on parties & -0.585 & (12.05) & & & & \\
\hline & Spending on gambling & -0.279 & $(7.07)$ & & & & \\
\hline & Total individual consumption & 882.6 & $(674.90)$ & -882.6 & -1151 & -867.1 & -527.3 \\
\hline \multirow[t]{8}{*}{ Transfers: } & Transfers to others (spouse, children, other) & 106.9 & $(234.60)$ & -106.9 & -81.73 & -122.9 & -122.3 \\
\hline & Transfers from spouse & 367.6 & (298.00) & 367.6 & 464.4 & 473.6 & 101.8 \\
\hline & Transfers from outside HH & 288 & $(512.60)$ & 288 & 191.4 & 307.9 & 376.3 \\
\hline & Informal loans given & -49.87 & (64.34) & 49.87 & 96.1 & 36.73 & 1.582 \\
\hline & Gifts Given & 4.205 & (37.11) & -4.205 & -3.279 & 10.1 & -23.15 \\
\hline & Informal loans received & -156.9 & $(174.20)$ & -156.9 & -324.3 & -49.08 & -56.33 \\
\hline & Gifts Received & 24.36 & $(23.51)$ & 24.36 & 13.23 & 22.18 & 42.58 \\
\hline & $\begin{array}{l}\text { Total cash balance sum of headwater } \\
\text { Number of observations: } 9,168 \\
\text { Number of households: } 782\end{array}$ & oefficie & & $-1,202.71$ & $-1,212.28$ & $-1,162.00$ & -909.12 \\
\hline
\end{tabular}


Table A5. Intrahousehold Transfers.

\begin{tabular}{|c|c|c|c|c|c|c|c|c|c|}
\hline & $\begin{array}{c}\text { Survey } \\
\text { Experiment } \\
\text { 'Sin Goods' } \\
\text { Consumed }\end{array}$ & $\begin{array}{c}\text { Monthly } \\
\text { Individual } \\
\text { Consumption }\end{array}$ & $\begin{array}{c}\text { Monthly } \\
\text { Household } \\
\text { Consumption }\end{array}$ & $\begin{array}{l}\text { Monthly } \\
\text { transfers to } \\
\text { Spouse }\end{array}$ & $\begin{array}{l}\text { Monthly } \\
\text { transfers to } \\
\text { Children }\end{array}$ & $\begin{array}{l}\text { Monthly } \\
\text { transfers to } \\
\text { Everyone }\end{array}$ & $\begin{array}{c}\text { Monthly } \\
\text { Transfers } \\
\text { from Spouse }\end{array}$ & $\begin{array}{c}\text { Monthly } \\
\text { Transfers } \\
\text { from Outside } \\
\text { Household }\end{array}$ & $\begin{array}{c}\text { Total } \\
\text { Monthly } \\
\text { Savings }\end{array}$ \\
\hline \multicolumn{10}{|l|}{ Baseline Characteristics: } \\
\hline Treated $*$ Female & $\begin{array}{c}-0.0314 \\
(0.05)\end{array}$ & $\begin{array}{c}-903.3 \\
(1260.00)\end{array}$ & $\begin{array}{c}-670.7 \\
(1303.00)\end{array}$ & $\begin{array}{c}-201.8 \\
(323.60)\end{array}$ & $\begin{array}{l}-25.82 \\
(44.52)\end{array}$ & $\begin{array}{c}-319.4 \\
(350.70)\end{array}$ & $\begin{array}{c}-94.1 \\
(410.30)\end{array}$ & $\begin{array}{c}-293 \\
(691.30)\end{array}$ & $\begin{array}{c}-674 \\
(529.20)\end{array}$ \\
\hline Treated (Male) & $\begin{array}{c}0.00977 \\
(0.04)\end{array}$ & $\begin{array}{c}2,149 * * \\
(1094.00)\end{array}$ & $\begin{array}{l}1,974 * * \\
(965.40)\end{array}$ & $\begin{array}{c}177.2 \\
(280.30)\end{array}$ & $\begin{array}{l}-21.57 \\
(36.76)\end{array}$ & $\begin{array}{c}277.1 \\
(308.80)\end{array}$ & $\begin{array}{c}417.8^{*} \\
(246.10)\end{array}$ & $\begin{array}{c}438 \\
(514.40)\end{array}$ & $\begin{array}{l}1,241 * * * \\
(450.40)\end{array}$ \\
\hline Constant & $\begin{array}{c}0.132^{* * *} \\
(0.02) \\
\end{array}$ & $\begin{array}{c}11,390 * * * \\
(616.20) \\
\end{array}$ & $\begin{array}{c}18,506^{* * *} \\
(607.90) \\
\end{array}$ & $\begin{array}{c}2,173^{* * *} \\
(146.40) \\
\end{array}$ & $\begin{array}{c}314.6^{* * *} \\
(23.44) \\
\end{array}$ & $\begin{array}{c}3,380^{* * *} \\
(174.40) \\
\end{array}$ & $\begin{array}{c}3,622 * * * \\
(200.20) \\
\end{array}$ & $\begin{array}{c}3,287 * * * \\
(343.40) \\
\end{array}$ & $\begin{array}{r}4,772^{* * * *} \\
(254.80) \\
\end{array}$ \\
\hline Observations & 1,986 & 9,168 & 9,168 & 9,168 & 9,168 & 9,168 & 9,168 & 9,168 & 9,168 \\
\hline R-squared & 0.017 & 0.009 & 0.031 & 0.012 & 0.017 & 0.012 & 0.013 & 0.005 & 0.012 \\
\hline Number of Individuals & 775 & 782 & 782 & 782 & 782 & 782 & 782 & 782 & 782 \\
\hline Control Group Mean & 0.1761 & 12,034 & 18,158 & 2,096 & 189 & 3,065 & 3,260 & 3,443 & 5,280 \\
\hline
\end{tabular}

Regressions include individual-level fixed effects and SEs are clustered at the individual level, regression includes month dummies and uses data for rounds 2-18.

* significant at $10 \%$; ** significant at $5 \%$; *** significant at $1 \%$ 
Table A6. Randomized Saturation Balance Tests.

\begin{tabular}{|c|c|c|c|c|c|c|c|c|c|c|}
\hline \multirow[b]{2}{*}{ Treated } & \multicolumn{2}{|c|}{$\begin{array}{c}\text { Number of Seetus currently } \\
\text { Participating in }\end{array}$} & \multicolumn{2}{|c|}{$\begin{array}{c}\text { Monthly amount Saved } \\
\text { through Seetus }\end{array}$} & \multicolumn{2}{|c|}{$\begin{array}{c}\text { Monthly Transfers FROM } \\
\text { Outside the Household }\end{array}$} & \multicolumn{2}{|c|}{$\begin{array}{l}\text { Monthly Transfers TO } \\
\text { Outside the Household }\end{array}$} & \multicolumn{2}{|c|}{$\begin{array}{l}\text { Total Monthly } \\
\text { Savings }\end{array}$} \\
\hline & $\begin{array}{c}-0.0653 \\
(0.18)\end{array}$ & $\begin{array}{l}0.122 \\
(0.27)\end{array}$ & $\begin{array}{c}35.86 \\
(321.5)\end{array}$ & $\begin{array}{c}361.2 \\
(437.8)\end{array}$ & $\begin{array}{c}150 \\
(836.3)\end{array}$ & $\begin{array}{c}64.11 \\
(964.5)\end{array}$ & $\begin{array}{r}-14.65 \\
(95.7)\end{array}$ & $\begin{array}{c}4.964 \\
(103.3)\end{array}$ & $\begin{array}{c}94.03 \\
(671.8)\end{array}$ & $\begin{array}{c}1005 \\
(805.3)\end{array}$ \\
\hline Seetu Treatment Saturation & & $\begin{array}{l}-0.93 \\
(0.82)\end{array}$ & & $\begin{array}{l}-1,619 \\
(1348.0)\end{array}$ & & $\begin{array}{c}427.60 \\
(2711.0)\end{array}$ & & $\begin{array}{l}-97.60 \\
(556.1)\end{array}$ & & $\begin{array}{l}-4,532 * \\
(2423.0)\end{array}$ \\
\hline Constant & $\begin{array}{c}2.066^{* * *} \\
(0.11) \\
\end{array}$ & $\begin{array}{c}2.065^{* * *} \\
(0.11) \\
\end{array}$ & $\begin{array}{l}2,244 * * * \\
(211.60) \\
\end{array}$ & $\begin{array}{c}2,244 * * * \\
(211.70) \\
\end{array}$ & $\begin{array}{l}4,509 * * * \\
(766.30) \\
\end{array}$ & $\begin{array}{l}4,510^{* * *} \\
(766.80) \\
\end{array}$ & $\begin{array}{c}502.6 * * * \\
(77.39) \\
\end{array}$ & $\begin{array}{c}502.6^{* * *} \\
(77.42) \\
\end{array}$ & $\begin{array}{l}5,471 * * * \\
(501.40) \\
\end{array}$ & $\begin{array}{r}5,469 * * * \\
(502.00) \\
\end{array}$ \\
\hline $\begin{array}{l}\text { Observations } \\
\text { R-squared }\end{array}$ & $\begin{array}{c}996 \\
0.001\end{array}$ & $\begin{array}{c}996 \\
0.006\end{array}$ & $\begin{array}{c}996 \\
0.002\end{array}$ & $\begin{array}{c}996 \\
0.008\end{array}$ & $\begin{array}{c}996 \\
0.004\end{array}$ & $\begin{array}{c}996 \\
0.004\end{array}$ & $\begin{array}{c}996 \\
0.003\end{array}$ & $\begin{array}{c}996 \\
0.003\end{array}$ & $\begin{array}{c}996 \\
0.005\end{array}$ & $\begin{array}{c}996 \\
0.008\end{array}$ \\
\hline
\end{tabular}

OLS with round fixed effects and standard errors clustered at the individual level. Table includes data from round 1-5 on households that were members of

ROSCAs within with the saturation experiment was conducted (no more than 24 ROSCA members all of whom lived in the same zone).

* significant at $10 \%$; ** significant at $5 \%$; *** significant at $1 \%$ 